Geology of the Ketchikan D-1 and Bradfield Canal A-1

Quadrangles,

Southeastern Alaska

GE OLOGICA L S U R E Y B ULLETIN 1425 



\section{Geology of the Ketchikan D-1}

and Bradfield Canal A-1

Quadrangles,

\section{Southeastern Alaska}

By JAMES G. SMITH

G E O L O G I C A L S U R V E Y B U L L E T I N 1425 


\section{UNITED STATES DEPARTMENT OF THE INTERIOR}

CECIL D. ANDRUS, Secretary

\section{GEOLOGICAL SURVEY}

V. E. McKelvey, Director

Library of Congress Cataloging in Publication Data

Smith, James G. 1939-

Geology of the Ketchikan D-1 and Bradfield Canal A-1 quadrangles, southeastern Alaska

Geological Survey Bulletin 1425

Bibliography: p. 48-49.

Supt. of Docs. No.: I19.3:1425

1. Geology-Alaska-Ketchikan region. I. Title. II. Series: United States Geological Survey Bulletin 1425 .

QE75.B9 no. 1425 [QE84.K47] 557'.3'08s [557.98'2]

$77-608000$

For sale by the Superintendent of Documents, U. S. Government Printing Office Washington, D. C. 20402

Stock Number 024-001-02960-0 


\section{CONTENTS}

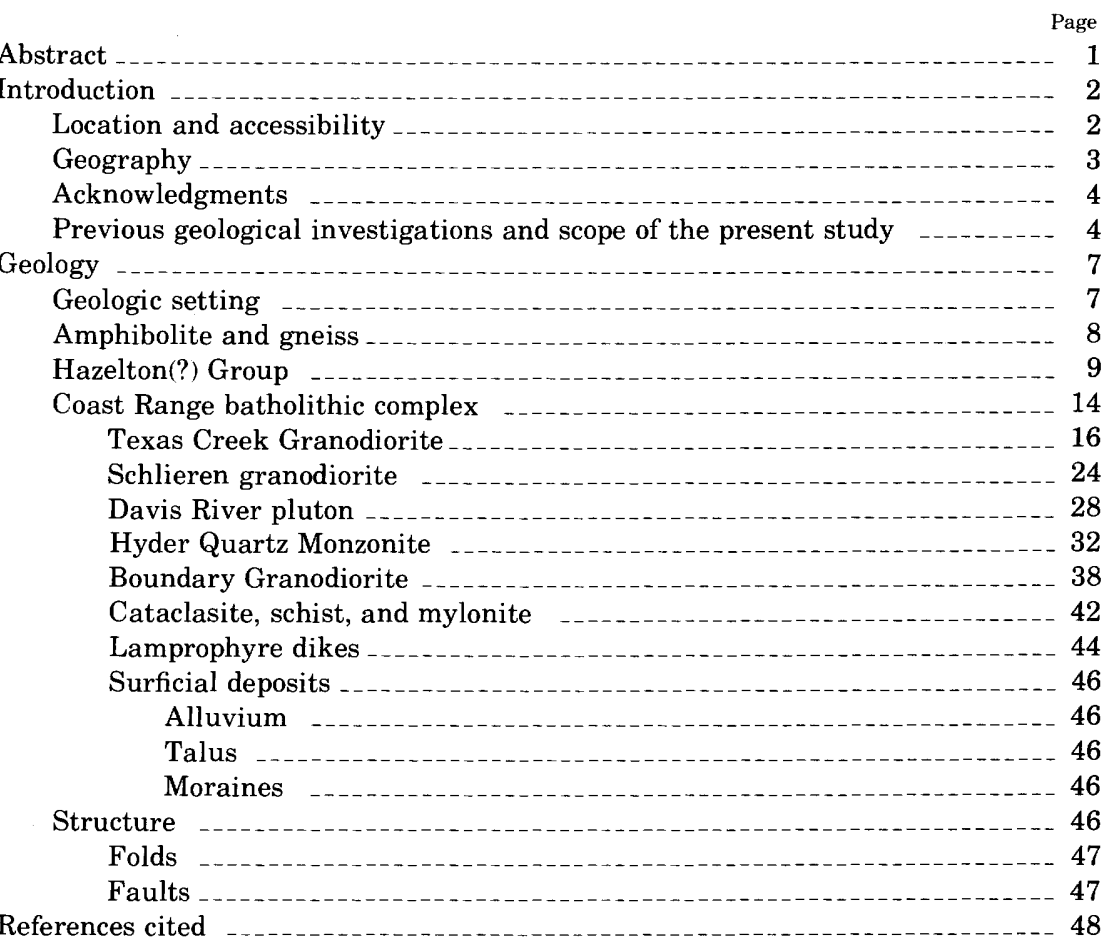

\section{ILLUSTRATIONS}

Plate 1. Geologic map of the Ketchikan D-1 and Bradfield Canal A-1 quadrangles, Alaska In pocket

Figure 1. Index map showing location of the Ketchikan D-1 and Bradfield Canal A-1 quadrangles, Alaska

2. Index map of geologically mapped areas near Hyder, Alaska, and Stewart, British Columbia

3. Modal classification of granitic rocks used in this report

4-8. Location and modal composition of samples from-

4. The Texas Creek Granodiorite _._. 20

5. Schlieren granodiorite -

6. The Davis River pluton

7. The Hyder Quartz Monzonite

8. The Boundary Granodiorite 


\section{TABLES}

TABLE 1. Chemical analyses of the Hazelton(?) Group, Hyder area, Alaska

2. Modes of Texas Creek Granodiorite

3. Modes of schlieren granodiorite pluton

4. Modes of Davis River pluton

(-

5. Modes of Hyder Quartz Monzonite

6. Modes of Boundary Granodiorite 


\title{
GEOLOGY OF THE KETCHIKAN D-1 AND BRADFIELD CANAL A-1 QUADRANGLES, SOUTHEASTERN ALASKA
}

\author{
By James G. Smith
}

\section{ABSTRACT}

The Ketchikan D-1 and Bradfield Canal A-1 quadrangles are in southeastern Alaska at the head of Portland Canal, along the British Columbia border. The area lies along the east border of the Coast Range batholithic complex and is underlain chiefly by intermediate granitic plutons that intruded, folded, and metamorphosed Mesozoic volcanic and volcaniclastic rocks. The metamorphic and intrusive rocks are cut by lamprophyre dikes. Surficial deposits of alluvium, talus, and moraines cover about 5 percent of the map area.

The presumed oldest, certainly the most metamorphosed, unit is composed of amphibolite and gneiss that forms small screens between plutons in the southern part of the Ketchikan D-1 quadrangle. The next oldest unit is a thick sequence of tightly folded and metamorphosed volcanic and volcaniclastic rocks that are exposed in the northern third of the map area and that are questionably assigned to the Hazelton Group.

Five separate plutons belonging to the Coast Range batholithic complex crop out within the map area. The oldest pluton, the Texas Creek Granodiorite, underlies more than $100 \mathrm{~km}^{2}$, intrudes the Hazelton(?) Group, and is about 200 million years old. It has been subsequently sheared and partly recrystallized. The Lindborg shear zone at the Riverside mine is a local zone of cataclasis within a broader shear zone in the Texas Creek Granodiorite.

The schlieren granodiorite underlies more than $65 \mathrm{~km}^{2}$ and is characterized by lithologic inhomogeneity at all scales and by strong planar and linear structures. The pluton grades from foliated to irregularly banded to gneissose over short distances and is intruded by the Hyder Quartz Monzonite and the Davis River pluton.

The Davis River pluton, only a small part of which lies in the map area, is composed of porphyritic coarse-grained biotite-hornblende granodiorite. Euhedral phenocrysts of potassium feldspar as large as $4 \mathrm{~cm}$ constitute up to 5 percent of the rocks. The pluton is intruded by the Hyder Quartz Monzonite.

The Hyder Quartz Monzonite crops out over more than $500 \mathrm{~km}^{2}$. It is typically a medium-grained hypidomorphic biotite-hornblende granodiorite with local phases of quartz monzonite. The pluton was intruded about 45 to 50 million years ago.

The north- to northeast-trending Fish Creek fault zone is the only major fault within the map area. In the Late Triassic or Early Jurassic, extensive regional shearing created a $1.5-\mathrm{km}$-wide zone of cataclasite, schist, and gneiss. About $4 \mathrm{~km}$ of rightlateral movement occurred at this time. After the intrusion of the Eocene Hyder Quartz Monzonite and the younger, lamprophyre dikes, recurrent right-lateral movement of up to $1 \mathrm{~km}$ took place, but without cataclasis. 


\section{INTRODUCTION}

\section{LOCATION AND ACCESSIBILITY}

The Ketchikan D-1 and Bradfield Canal A-1 quadrangles are at the head of Portland Canal in the center of the Coast Range Mountains of British Columbia and southeastern Alaska (fig. 1). The quadrangles are bounded on the east by long $130^{\circ} 00^{\prime}$ and on the south by lat $55^{\circ} 45^{\prime}$. Mount Welker, on the international boundary in the Bradfield Canal A-1 quadrangle, is the easternmost point in Alaska. The Alaskan-Canadian boundary in Portland Canal and roughly along the crest of the Coast Range forms the east and north margins of the area mapped in this report (pl. 1).

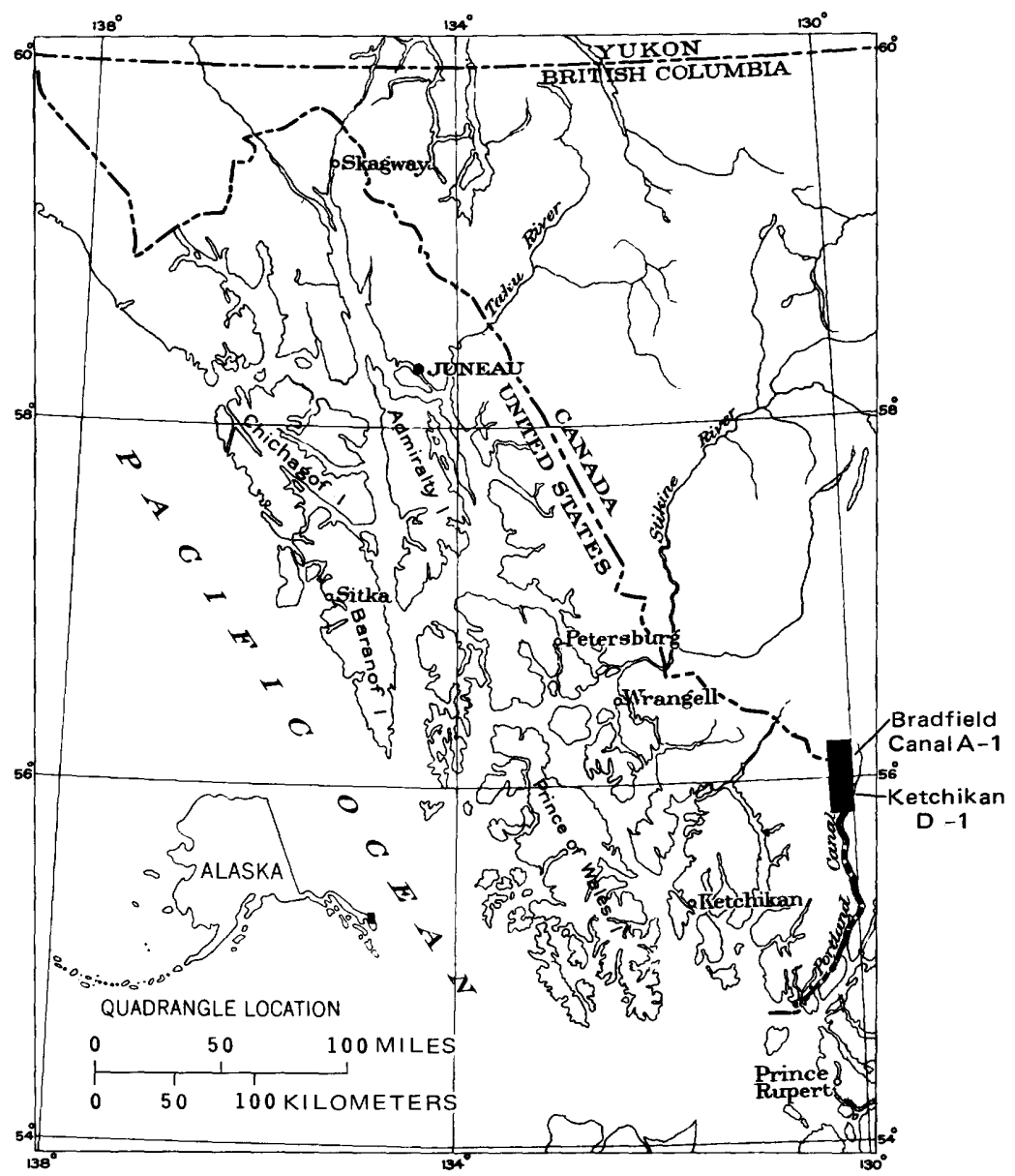

Figure 1.-Index map showing location of the Ketchikan D-1 and Bradfield Canal A-1 quadrangles, Alaska. 
The village of Hyder, $130 \mathrm{~km}$ from Ketchikan, at the mouth of the Salmon River, is the only permanent settlement in the map area. An all-weather road connects Hyder with the larger town of Stewart, British Columbia, $2.5 \mathrm{~km}$ to the northeast at the mouth of the Bear River. During the summer, daily flights from Stewart to Prince Rupert, B.C., are available, and regular steamer service brings supplies. Hyder is not served by scheduled transport, but charter aircraft are available in Ketchikan.

There are few roads within the quadrangles and adjacent areas. An all-weather public road extends from Hyder up the Salmon River to the international boundary. Beyond the border the road is privately maintained and serves the Granduc mine. Prior to 1967 it was possible to drive several kilometers up Texas Creek, but a flash flood resulting from rapid emptying of glacier-dammed Summit Lake washed out the bridge over the Salmon River (Grove, 1968). In British Columbia, a road is under construction that will connect Stewart with Cassiar and the Alaska Highway. A network of logging roads extends north from Terrace on Provincial Highway 16 toward Stewart. Local inquiry should be made before attempting to use these roads.

The Salmon River and its tributaries limit access on foot within the quadrangles. The lower slopes of mountains are cloaked with nearly impenetrable vegetation, and trails are quickly overgrown. Access to the back country and mountain ridges is nearly impossible without helicopter assistance.

\section{GEOGRAPHY}

Climate.-The Ketchikan D-1 and Bradfield Canal A-1 quadrangles lie in a climatic zone that is dominantly maritime. Precipitation is abundant year round, and temperatures are comparatively mild. Distance from the open ocean, rugged topography, and inland location create cooler summer and winter temperatures, less rainfall, but greater snowfall in comparison to coastal areas of southeastern Alaska. At Hyder the coldest month is February, with a mean temperature of $-3.7^{\circ} \mathrm{C}$. June, July, and August are the warmest months, with mean temperatures in the low teens (U.S. Weather Bureau, 1943). Mean annual precipitation is nearly $250 \mathrm{~cm}$. Statistically, May, June, and July are the driest months, but even then heavy precipitation is common.

Snowfall is strongly dependent on elevation. Mean annual snowfall at Hyder (sea level) is about $430 \mathrm{~cm}$; at the Premier mine, just across the border in British Columbia (304.8 m elevation), $1,016 \mathrm{~cm}$; and at Tide Lake Flats, near the crest of the Coast Range (914.4 m elevation), about 2,540 cm (U.S. Weather Bureau, 1943; Grove, 1971). At 
the higher elevations, large areas remain covered by snow until late in the summer.

Despite the heavy snowfall in the mountains, nearly all glaciers in the map area are retreating. Texas Glacier has retreated more than $1.6 \mathrm{~km}$ since 1924 . Historical positions of glacier fronts determined from aerial photographs and maps are indicated on plate 1 .

Vegetation.-On the lower mountain slopes, the mild climate and heavy rainfall nourish a luxuriant, almost junglelike, growth typical of the Coast Ranges. The tree line ranges from 760 to $1,000 \mathrm{~m}$ elevation. Below the tree line are magnificent climax forests of hemlock and spurce whose floors are carpeted with mosses, ferns, and berry bushes. Steep slopes, clearings, and partly healed avalanche paths are covered by thickets of slide alder, salmon berry, mountain ash, stinging nettle, and devil's club. If not constantly recleared, trails and roads are overgrown in a few years. The only areas free of the thick vegetation below the tree line are active talus cones, recent avalanche paths, cliffs, braided stream bottoms, soilless areas recently emerged from beneath glaciers, and the littoral zone along Portland Canal. Above $760-1,000 \mathrm{~m}$ the tall forests give way to heather meadows and stunted clumps of spruce. Patches of muskeg fill small depressions and poorly drained areas. Above $1,220 \mathrm{~m}$ plant life consists of small patches of lichens on bare rock and a few clumps of grass and moss in sheltered crevices.

Topography.-The topography of the area is typical of recently glaciated mountainous terrane. Relief is high. Precipitous valley walls rise $900-1,200 \mathrm{~m}$ from broad U-shaped valley bottoms to accordant rounded hummocky ridges. Many valley walls are spectacular bare cliffs down which tumble streams of meltwater. These streams join to form the swift rivers that rush down all major valleys.

The ridges below about $1,800 \mathrm{~m}$ were smoothed and rounded by overriding ice of the Pleistocene glaciers. Many of the broader ridges, as low as $1,370 \mathrm{~m}$, are still partly covered by capping glaciers and year-round snowfields. The higher peaks along the international boundary, which rise as high as $2,130 \mathrm{~m}$, stuck above the Pleistocene ice as nunataks and remain as sharp horns and aretes surrounded by the much smaller icefields of the present day.

\section{ACKNOWLEDGMENTS}

I am grateful to the many people who helped in the fieldwork and laboratory phases of this project. A. L. Clark, W. H. Condon, and C. C. Hawley all visited me in the field and helped in mapping, and G. C. Dunne and M. H. Herdrick ably served as field assistants. The work benefited greatly from discussions with my colleagues R. L. Elliott and H. C. Berg, who mapped the adjacent Granite Fjords wilder- 
ness study area. I also thank T. W. Grove of the British Columbia Department of Mines and Petroleum Geology for field trips and discussions on the relations and structure of their Hazelton and Bowser assemblage. Discussions with W. W. Hutchison and J. A. Roddick of the Geological Survey of Canada on the Coast Range batholith and field trips in the Prince Rupert-Terrace area were very helpful and much appreciated. Modal counts not done by the author were done by P. A. Frame and R. J. Wehr.

\section{PREVIOUS GEOLOGICAL INVESTIGATIONS AND SCOPE OF THE PRESENT STUDY}

Geologic studies in the Hyder-Stewart area have followed general interest in mining. The area was first prospected around the turn of the century as an outgrowth of the Klondike gold rush. Grove (1971, p. 18) gives an interesting account of the "discovery" of the district and its early history. Brief reconnaissance studies by members of the U.S. Geological Survey and the Geological Survey of Canada (Westgate, 1922; Schofield and Hanson, 1920) followed the early prospectors' discoveries. Often hampered by the difficult terrain and weather, these workers concentrated on physical description, the broader geological features, and descriptions of individual mining properties.

The early reports were followed by more detailed large-scale mapping on both sides of the border. Mapping was still confined mostly to the shores of Portland Canal, the major rivers and areas accessible by trails cut through the bush to mines and prospects. A. F. Buddington (1929) produced the first detailed geological map on the American side of the border to accompany his report on the Hyder area (fig. 2). His descriptions of the granitic rock units were especially complete for the time, and the names he gave to units remain in use today. On the Canadian side of the border, the metamorphic rocks are more prominent and were correspondingly more thoroughly described and named by Hanson $(1929,1935)$, who produced the first detailed map of the Stewart area.

A long period of quiescence followed as prospecting subsided and the few profitable mines were developed. There was a brief flurry of activity during World War II, sparked by exploration for essential commodities, such as tungsten (Byers and Sainsbury, 1957). In the past few years as helicopter-assisted exploration and mapping have opened up the formerly inaccessible back country, new discoveries have been followed by modern, detailed large-scale geologic maps. The early maps by Hanson have been extended by Grove (1971) adjacent to the border in British Columbia, while the present study extends the work of Buddington (1929) on the American side. 


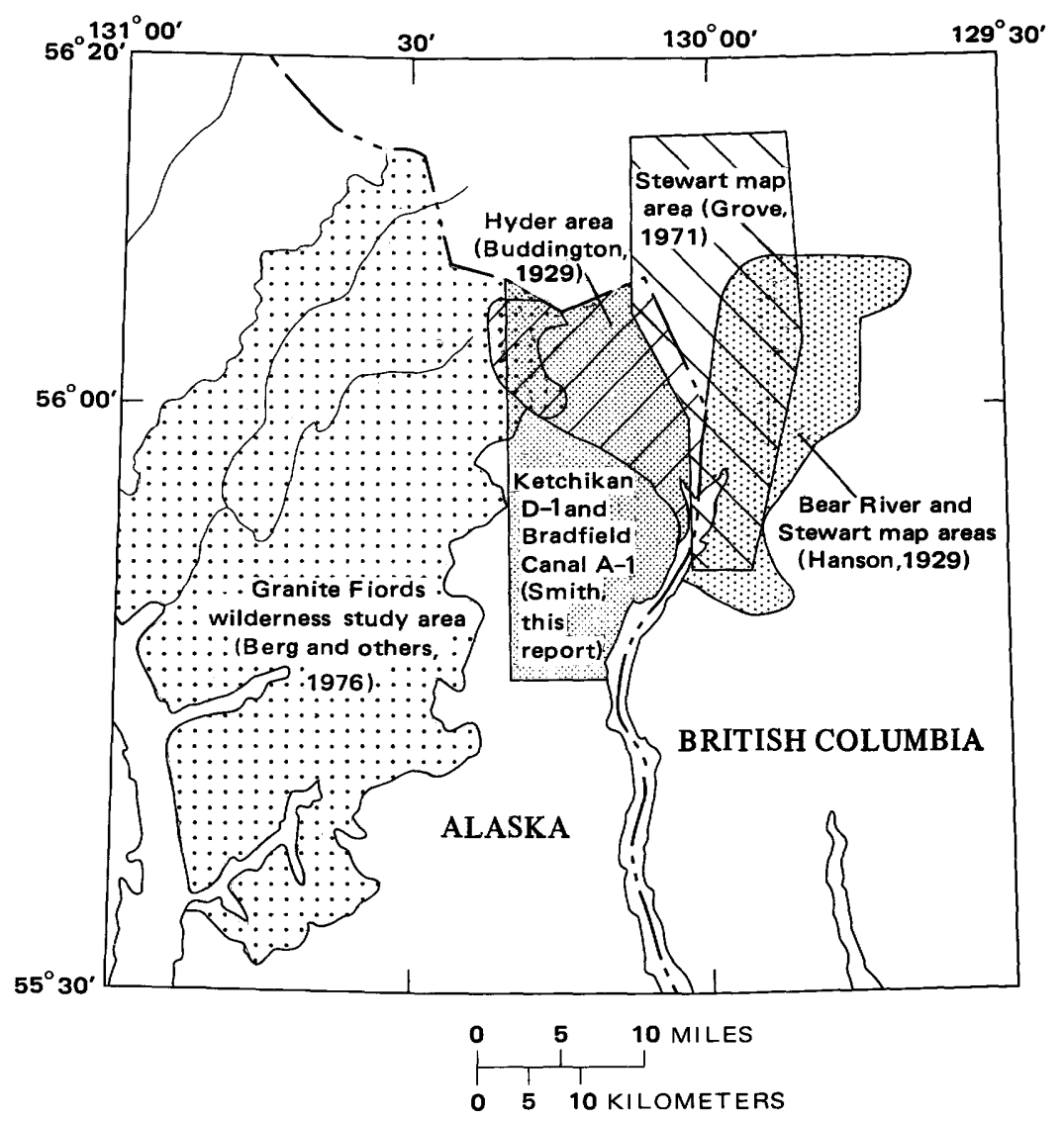

FiguRE 2.-Index map of geologically mapped areas near Hyder, Alaska, and Stewart, British Columbia.

The fieldwork on which the present report is based was done during June, July, and part of August 1968. A few additional samples were collected by H. C. Berg for the author in 1972. Mapping was done on foot, in a four-wheel drive vehicle, in a skiff along the shoreline, and, for approximately 3 weeks, by helicopter. Standard mapping techniques were used, and geology was plotted on mylar maps at 1:48,000 scale enlarged from 1:63,000. Aerial photographs were used to delineate surficial deposits and for detailed mapping of the Fish Creek fault zone. In addition, geochemical samples were collected in an effort to assess the resource potential of the area. The results of that study are described elsewhere (Allen Clark, Michael Estlund, and James Smith, unpub. data). 


\section{GEOLOGY}

\section{GEOLOGIC SETTING}

Most of the Ketchikan D-1 and Bradfield Canal A-1 quadrangles are underlain by intermediate granitic plutons that intruded folded and metamorphosed Mesozoic volcanic and volcaniclastic rocks. The metamorphic and granitic rocks are cut by lamprophyre and porphyritic dikes. The lamprophyre dikes are part of a much larger province (Smith, 1973), and the porphyritic dikes are offshoots of the different granitic plutons. Surficial deposits are abundant in valleys and near glaciers.

The granitic plutons in the Ketchikan D-1 and Bradfield A-1 quadrangles are part of the composite Coast Range batholith that extends the length of coastal British Columbia and southeastern Alaska from Vancouver to Skagway. In the map area, these plutons form the northeast border of the batholith. The batholith is not uniform from southeast to northwest, but rather grades from elongate gneissic and migmatitic diorite and quartz diorite plutons along its southwest side to structureless and more equant granodiorite and quartz monzonite plutons to the northeast. The plutons are calcalkalic in composition; alkaline and subalkaline rocks are lacking (Hutchison, 1966). Radiometric data indicate a long intrusive history extending from the Jurassic into the Eocene.

Southwest of the batholith lie the regionally metamorphosed sedimentary and volcanic schists and gneisses of the WrangellRevillagigedo metamorphic belt (Buddington and Chapin, 1929, p. 49-74). The transition between the Coast Range batholith and the Wrangell-Revillagigedo metamorphic belt is marked by a zone of intimately related migmatites, gneissic plutonic bodies, and high-grade gneisses. Metamorphic grade within the belt decreases from a sillimanite and kyanite zone near the contact with the Coast Range batholith to a chlorite zone along Revillagigedo Channel and Chatham Sound. The small amphibolite and gneiss unit in this report is part of the high-grade gneiss.

No zone comparable to the high-grade regionally metamorphosed rocks exists along the northeast side of the batholith in the Hyder area. Instead, there is a narrow zone of hornfelsed volcanic and volcaniclastic rocks. Metamorphic grade decreases rapidly to the northeast and gives way to the gently folded and largely unmetamorphosed rocks of the Bowser Basin.

Hundreds of lamprophyre dikes were injected after consolidation of the Coast Range plutons. These dikes cut across the preexisting northwest grain of the country rocks with only minor movement and dilation. 
Strong regional uplift and erosion in late Cenozoic time unroofed the batholith and surrounding metamorphic rocks. Glaciation carved deep, steep-walled valleys and smooth alpine ridges. Abundant surficial deposits remain as a result of glaciation, and erosion and deposition continues to the present day.

\section{AMPHIBOLITE AND GNEISS}

Amphibolite and gneiss crop out in four small elongate roof pendants between plutons of different ages in the southwestern part of the Ketchikan D-1 quadrangle. Three pendants are more than 1.6 $\mathrm{km}$ long, but only one is more than $400 \mathrm{~m}$ wide. Little is known about them as they were not studied in detail, and metamorphism has obliterated original features.

Contacts with the enclosing plutons are generally sharp, although local border zones of migmatite occur. Foliation within each pendant is strongly developed parallel to contacts with the enclosing plutons. Lineations, where present, plunge steeply down the dip of the foliation.

The most common rock is amphibolite. Light-colored biotite-quartz gneiss and schist constitute less than 20 percent. The amphibolite is a strongly foliated fine- to medium-grained dark-colored rock composed of hornblende and plagioclase with less than 25 percent biotite and quartz. Minor or accessory minerals that constitute less than a percent or two are magnetite, pyrite, sphene, and epidote. Compositional layering may or may not be present.

Plagioclase in amphibolite, schist, and gneiss is xenomorphic, clear, and unzoned or rarely faintly zoned. No sample contained premetamorphic plagioclase. Only 10-20 percent of grains in a sample are twined, which makes identification of plagioclase difficult. The plane (010) is often alined parallel to the foliation, and many crystals are elongated in that direction. Composition is highly variable from sample to sample and ranges from $\mathrm{An}_{25}$ to $\mathrm{An}_{75}$. Within any one sample anorthite content rarely varies more than 5-10 percent.

Amphibole is idiomorphic or subidiomorphic. Both tremoliteactinolite and hornblende are present, although not in the same sample. Tremolite-actinolite is colorless and occurs in samples with less calcic plagioclase. Hornblende is green or brown and is associated with more calcic plagioclase.

Quartz is common in schist and gneiss but not in amphibolite. In both rocks it is xenomorphic, fine grained, clear, and easily confused with plagioclase.

Biotite is less abundant in amphibolite than in gneiss and schist. It is strongly pleochroic, the darker direction being a deep reddish brown. It forms distinct flakes that are locally partly altered to chlorite. 
The amphibolite and gneiss were first regionally metamorphosed and then contact metamorphosed, probably more than once, during the intrusion of younger plutons. Contact metamorphic textures are more conspicuous than regional textures, which were largely destroyed. Precise grade of metamorphism is difficult to determine as diagnostic pelitic mineral assemblages are absent. The presence of hornblende and plagioclase more calcic than $\mathrm{An}_{20}$ suggests that the lower part of the hornblende-hornfels facies was obtained at least locally. Elsewhere the association tremolite-actinolite and plagioclase less calcic than $\mathrm{An}_{20}$ are indicative of the albite-epidoteamphibolite facies.

The age and origin of the amphibolite and gneiss unit are unknown. No fossils were found, and no premetamorphic features seen. In metamorphic grade and thoroughness of recrystallization, the unit is unlike the Hazelton(?) Group described below, although parts of the two units probably have similar chemical compositions. It more closely resembles similar metamorphic rocks mapped to the southwest in the Granite Fiords wilderness study area (H. C. Berg, oral commun.) with which it is probably correlative. It is therefore considered to be Jurassic or older.

\section{HAZELTON(?) GROUP}

\section{NAME AND GENERAL RELATIONS}

A thick sequence of volcaniclastic rocks exposed in the northern part of the map area is questionably assigned to the Hazelton Group. These rocks are lithically and structurally equivalent to rocks assigned to the Hazelton Group by Buddington (1929) in the Hyder area and by Grove (1971) in the adjacent Stewart map area; individual beds and structures can be easily traced across the international boundary. In neither area has the base of this sequence been recognized, and only nondiagnostic fossil fragments have been found. In the Stewart area these rocks are unconformably overlain by Middle Jurassic (Bajocian or Bathonian) sedimentary rocks of the Bowser assemblage of Grove (1971, p. 37). In the Hyder area, the top has not been recognized. Assignment of this thick sequence of volcaniclastic rocks to the Hazelton Group by Buddington (1929, p. 17) and Grove (1971, p. 42) was based in part on previous usage of the name and in part on lithic correlation with the type Hazelton near the town of Hazelton, British Columbia. I am not sure that assignment of these rocks to the type Hazelton is correct in view of lack of direct fossil evidence and the fact that they are intruded by a Late Triassic or Early Jurassic pluton (p. 42-45). The rocks are, therefore, questionably assigned to the Hazelton Group.

Interbedded tuff-breccia, volcanic graywacke, and argillite are the 
dominant rocks in the Hazelton(?) Group. Less common rocks include coarse tuff-breccia, coarse volcanic conglomerate, possible broken pillow breccia, and beds of dark-blue-gray marble. Nonvolcanic detritus is rare. Flows or pillow lavas were not seen. In the older literature, porphyries, commonly called the "Premier porphyries," were described. However, when reexamined first by E. W. Grove and then by me, the so-called porphyries were found to be coarse-grained volcanic graywacke, locally cataclastically deformed. The plagioclase "phenocrysts" were found to be detrital feldspar grains (Grove, 1971, p. 43).

Outcrops of the Hazelton(?) Group are smooth and rounded where recently uncovered by retreating glaciers. Elsewhere outcrops are angular and jagged owing to weathering along numerous intersecting joint and foliation surfaces. Weathered surfaces are mostly gray to black, although near intrusions they are commonly iron stained owing to weathering of pyrite. On freshly broken surfaces, the coarser grained rocks are dull shades of green or less commonly purple, reddish brown, or gray. Finer grained volcaniclastic rocks are gray to black.

The Hazelton(?) Group is confined to the northern part of the map area, where it crops out in three principal areas. The largest and best exposed area lies near the junction of Chickamin Glacier, Through Glacier, and the headwaters of Texas Creek. This area is the remnant of an arched roof over the Texas Creek Granodiorite. Cleavage and foliation generally strike northeast and dip at low angles to the north or northwest.

The second area lies between Fish Creek fault zone and the international boundary. It is part of a much larger area of Hazelton(?) Group that extends north along Big Missouri and Bear River Ridges into British Columbia. Areas above $900 \mathrm{~m}$ elevation have excellent exposures, but lower elevations are largely covered by vegetation and soil. Foliation and cleavage in this area strike east-west and dip nearly vertically. Cataclasites and sheared rocks are common.

The third area is in the vicinity of Mineral Hill. This area is covered with dense vegetation and intruded by dike swarms emanating from the Hyder Quartz Monzonite; outcrops are few and generally deeply weathered.

All of this sequence within the map area was subjected to low-grade regional metamorphism and locally to subsequent overprinting contact metamorphism caused by intrusion of both the Texas Creek Granodiorite and middle Tertiary plutons. The rocks were also tightly folded, locally even isoclinally folded and overturned. In palces shearing formed fine-grained cataclastic rocks. Despite metamorphism, enough original features are preserved at most out- 
crops so that the original rock name can be used, and to avoid repetition, the prefix "meta" is generally dropped.

\section{PETROGRAPHY}

Original volcanic and depositional features are preserved in all but the most metamorphosed rocks. Tuff-breccias are massive and usually $1 / 2-4 \mathrm{~m}$ thick or more. The thicker a bed, the larger is its average clast size and the more obscure are internal stratification or other depositional features. Argillite and graywacke are interlaminated on a centimeter scale, but locally folding and transposition of bedding preclude estimating original thicknesses. Graded bedding, load casts, and flame structures are common.

Tuff-breccia consists of 5-50 percent poorly sorted angular to subrounded lapilli, set in an unsorted and unstratified volcanic graywacke matrix. Phenocrysts of euhedral, zoned plagioclase from 1 $\mathrm{mm}$ to $1 \mathrm{~cm}$ long constitute 5-20 percent of the lapilli. They have largely recrystallized to albite or oligoclase and clinozoisite-epidote, but those that survived metamorphism retain their original andesine composition. Most plagioclase phenocrysts are milky white or dull green in hand specimen owing to recrystallization. Phenocrysts of mafic minerals are much less common than plagioclase; most lapilli contain none at all. Where mafic minerals are present, strongly pleochroic euhedral green or brown hornblende is more common than colorless subcalcic augite. Olivine is absent. Most mafic phenocrysts have recrystallized to masses of actinolite, chlorite, and opaque minerals. Vessicles are rare, and pumiceous lapilli are absent. Groundmasses of the lapilli have mostly recrystallized to nearly submicroscopic aggregates of albite-quartz-chlorite-epidote and opaque minerals with or without quartz, although shapes suggestive of microlites are still visible in some specimens. Primary textures were most likely felty, glassy, and intergranular.

The graywacke matrix of the tuff-breccia is composed of sand-sized angular mineral fragments identical to phenocrysts in lapilli and a pasty filling that was probably tiny crystal fragments and glass particles before metamorphic recrystallization. Increased metamorphism blurs the more delicate features of clasts and grains as well as boundaries between clasts and groundmass.

Volcanic graywacke, volcanic sandstone, and argillite occur in interlaminated sequences with local dominance of one type or the other. Individual beds are $1 \mathrm{~mm}$ to $6 \mathrm{~cm}$ thick. Graded beds are commonly marked by accumulation of plagioclase crystals at the base. Load casts, flame structures, and other soft-sediment deformation features are not as common as graded beds. Composition and metamorphic textures of these sediments are similar to the interclast matrix of the 
tuff-breccia. Thin sections show angular grains of plagioclase, hornblende, and volcanic rock fragments. More than 95 percent of the grains are of volcanic derivation. They are set in an almost submicroscopic mosaic of metamorphic albite, chlorite, epidote, quartz, sericite, calcite, and opaque minerals recrystallized from the original matrix. Volcanic rock fragments are mashed and molded around other grains, further obscuring original textures. Many crystal clasts show angular outlines of broken original textures. Many crystal clasts show angular outlines of broken crystals in contrast to the euhedral phenocrysts in tuff-breccias.

\section{AGE AND ORIGIN}

A precise age for the Hazelton(?) Group in the Hyder-Stewart area is difficult to determine because the rocks lack fossils and are unsuitable for radiometric age determinations. Buddington (1929) and Grove (1971) correlated these rocks with the type Hazelton Group, as it was called by early workers. However, Buddington did so following Canadian authors, and Grove (1971, p. 38) states that, "Generally the Hazelton rocks are lithologically similar to the underlying Upper Triassic assemblage." The Hazelton(?) Group is intruded by the Texas Creek Granodiorite, and a radiometric age on that pluton would give at least a younger limit to the time of deposition of the volcaniclastic rocks. Potassium-argon dates on minerals from the Texas Creek Granodiorite, although discordant owing to partial thermal resetting of mineral ages, suggest that the pluton was intruded in the Late Triassic or Early Jurassic. This in turn suggests that the Hazelton(?) Group in the Hyder-Stewart area may be Late Triassic or Early Jurassic and thus older than believed by other authors.

The origin of this volcaniclastic sequence also poses problems. Two important questions are (1) under what conditions was it deposited and (2) what was the source of the great volume of tuff-breccia and interstratified finer volcaniclastic rocks?

I believe that most if not all of the Hazelton(?) Group was deposited in water, probably sea water. However, Grove (1971, p. 41-42) states that it is nonmarine on the basis of "the apparent absence of invertebrate marine fossils, the repetition of red beds, possibly denoting strongly oxidizing conditions and scattered evidence of coal fragments." Direct evidence for aqueous deposition consists of limestone interbedded within the unit and thick sequences of thin-bedded finegrained volcaniclastic rocks with graded bedding and load casts. These features are not found in subaerial deposits and are rare in fresh-water deposits. The lack of pumiceous lapilli is also indirect evidence for subaqueous, rather than subaerial deposition. The lack of fossils can be attributed to an unfavorable environment caused by 
extremely rapid deposition of vast quantities of volcanic debris. In other sequences of interbedded volcaniclastic and nonvolcaniclastic deposits, fossils are usually restricted to the nonvolcanic parts (Carlisle, 1963; Smith and MacKevett, 1970). Although red beds can form in an oxidizing subaerial environment, red volcaniclastic rocks can also form underwater. The plant material from which the coaly material came probably originated on land but could very well have been sluiced in. Coaly fragments are common in turbidite and marine volcaniclastic deposits elsewhere (Fiske and others, 1963, p. 10; Bouma and Hollister, 1973, p. 95).

The tuff-breccias are interstratified with the thinly bedded volcanic rocks, indicating that the tuff-breccias were also deposited under water. Similar thick units are interpreted by Fisk, Hobson, and Waters (1963, p. 16-17) and Carlisle (1963) as subaqueous volcanic mudflows, and the thinly laminated finer grained parts of the sequence as turbidites.

Most of the rocks were derived from intermediate volcanic sources. The high content of hornblende and intermediate plagioclase, the lack of abundant pyroxene, and absence of olivine indicate that most of the volcanic debris was andesitic in composition. Three analyses (table 1) of the Hazelton(?) Group, one of them a sill, bolster this

TABLE 1.-Chemical analyses of the Hazelton (?) Group, Hyder area, Alaska

[Analysts, Paul Elmore, Hezekiah Smith, Gillison Chloe, James Kelsey, and James Glen. Samples were analyzed by rapid-rock analysis methods similar to those described by Shapiro and Brannock (1956)]

\begin{tabular}{|c|c|c|c|}
\hline Laboratory No _...... & $\begin{array}{c}1 \\
\text { M112 } \\
961 \mathrm{~W}\end{array}$ & $\begin{array}{l}2 \\
\text { M112 } \\
192 W\end{array}$ & $\begin{array}{c}3 \\
\text { M112 } \\
963 W\end{array}$ \\
\hline Field No & $\begin{array}{c}68 \mathrm{ASJ} \\
135 \\
\end{array}$ & $\begin{array}{c}\text { 68ASJ } \\
155\end{array}$ & $\begin{array}{c}68 \mathrm{ASJ} \\
166 \mathrm{C} \\
\end{array}$ \\
\hline $\begin{array}{l}\mathrm{SiO}_{2} \\
\mathrm{Al}_{2} \mathrm{O}_{3} \\
\mathrm{Fe}_{2} \mathrm{O}_{3} \\
\mathrm{FeO} \\
\mathrm{MgO} \\
\mathrm{CaO} \\
\mathrm{Na}_{2} \mathrm{O} \mathrm{O}_{\mathrm{K}} \\
\mathrm{K}_{2} \mathrm{O} \mathrm{H}_{2} \\
\mathrm{H}_{2} \mathrm{O}+ \\
\mathrm{TiO}_{2} \mathrm{~T}_{2} \\
\mathrm{P}_{2} \mathrm{O}_{5} \\
\mathrm{MnO} \mathrm{CO}_{2}\end{array}$ & $\begin{array}{c}59.6 \\
15.9 \\
.49 \\
6.1 \\
3.3 \\
5.9 \\
3.2 \\
2.7 \\
.87 \\
.12 \\
.76 \\
.42 \\
.18 \\
<.05 \\
\end{array}$ & $\begin{array}{r}54.2 \\
15.9 \\
4.4 \\
3.1 \\
2.7 \\
6.0 \\
2.8 \\
3.0 \\
2.4 \\
.09 \\
.62 \\
.66 \\
.14 \\
3.1 \\
\end{array}$ & $\begin{array}{r}56.2 \\
13.1 \\
1.6 \\
10.5 \\
2.3 \\
4.4 \\
2.9 \\
2.0 \\
2.5 \\
.13 \\
2.0 \\
.95 \\
.26 \\
.62 \\
\end{array}$ \\
\hline Total (rounded) & 100 & 99 & 99 \\
\hline
\end{tabular}

1. Thinly interbedded volcaniclastic graywacke and siltstone; collected southwest of Mount Jefferson Coolidge at approximate elevation of 5,500 feet; $6217025 \mathrm{~N}$, $421800 \mathrm{E}$, zone 9 UTM, Bradfield Canal A-1 quadrangle.

2. Semischistose chlorite-epidote-albite metavolcanic tuff-breccia; collected north of Mount Dolly at approximately 4,300 feet; $6259825 \mathrm{~N}, 436925 \mathrm{E}$, zone 9 UTM; Ketchikan D-1 quadrangle.

3. Hornfelsed andesite sill containing microphenocrysts of plagioclase to $1 \mathrm{~mm}$ long. collected on ridge between Greenpoint and Hummel Glaciers at approximately 5,400 feet elevation; 6209075N, 421225E, zone 9 UTM; Bradfield Canal A-1 quadrangle. 
argument as all have silica content and total-alkali-to-silica ratios typical of andesites.

The volcanic composition of all the clasts and the abudnace of unrounded lapilli and angular plagioclase and hornblende crystals indicate that the debris was transported only a short distance from nearby volcanic sources, probably explosive underwater eruptions. The material was deposited at about the same time as its eruption. The unstratified tuff-breccia deposits are pictured as large underwater debris flows that originated on the flanks of nearby vents. The finer grained interlaminated deposits represent a mixture of turbidity current deposits and layers that formed as the finer debris from the subaqueous eruptions settled to the ocean floor. The volcaniclastic rocks were not derived by erosion of older consolidated volcanic rocks exposed on land and are thus most accurately classified as underwater pyroclastic deposits, rather than as epiclastic deposits.

\section{COAST RANGE BATHOLITHIC COMPLEX}

Granitic rocks underlie more than $840 \mathrm{~km}^{2}$ in the Ketchikan D-1 and Bradfield Canal A-1 quadrangles, an area larger than that of any other rock type. Five separate granitic plutons were mapped on the basis of differences in mineral content, internal structure, texture, and age. Only a small part of two of the plutons (schlieren granodiorite and Davis River pluton) crop out within the map area, and their full extent and internal structures are largely unknown. Another pluton, the Boundary Granodiorite, may be an offshoot of the largest pluton in the area, the Hyder Quartz Monzonite, but relations between the two units are largely obscured by ice and snow.

In the field, plutons can be distinguished from one another on the basis of distinctive texture and composition. Many contacts between plutons are marked by thin steeply dipping discontinuous metamorphic screens. Plutons are internally zoned with borders generally more mafic than cores. In the field many subtle differences often went undetected only to show up during laboratory work. Further field study would probably show more intrusive phases and compositional differences than are shown on plate 1 .

Modal analyses were used to classify the granitic rocks after the system used by Moore (1963) and Bateman, Clark, Huber, Moore, and Rinehart (1963) (fig. 3). In this classification, the placement of lines between the fields is slightly different from those used by most Canadian authors (for example, Hutchison, 1970, p. 390). More rocks are classified as quartz diorite and fewer as granodiorite than in the Canadian system. Modes of individual samples range in composition from quartz diorite to quartz monzonite and alaskite. The average 


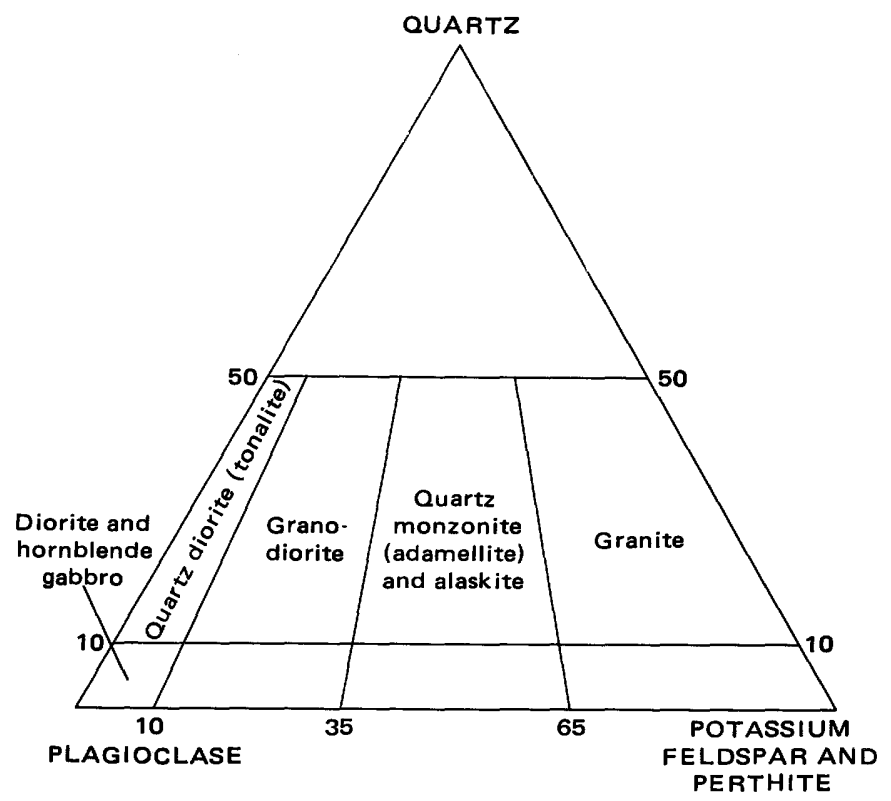

FigURE 3.-Modal classification of granitic rocks used in this report.

mode of most plutons lies near the boundary between granodiorite and quartz monzonite.

All plutons in the Hyder area were originally assigned a Jurassic or Cretaceous age by Buddington (1929). No reasons were given for this age other than that the plutons intruded the Hazelton Group, which was assigned a Jurassic(?) age. Buddington and Chapin (1929, p. 252-253), writing on the age of the Coast Range batholith in general, stated "the age of the Mesozoic intrusive rocks has not been definitely determined." Evidence used to establish the probable age of the batholith was based on widespread intrusive and unconformable relations between the batholith and older and younger rocks. Some evidence cited came from as far away as Whitehorse, Yukon Territory, and Vancouver Island.

Modern radiometric dating has established that emplacement of the Coast Range batholith took place over a longer interval and that much plutonism is younger than previously thought. Available radiometric data show that the eastern part of the batholith consists of a wide belt of plutons, most of which were emplaced 40-60 m.y. (million years) ago, and that the western part is older, perhaps as old as middle Cretaceous (Forbes and Engels, 1970; Hutchison, 1970).

Modal analyses were made on more than 90 slabs and thin sections of representative samples. Owing to the coarse grain size of most 
samples, slabs were preferred to thin sections. A rectangular grid was placed over the stained slab, and the minerals were tabulated. Six hundred points were counted, and the amounts of constituent minerals were recorded at each 100 points. If the abundance of a mineral showed fluctuations or consistent drift of more than a few percent at each 100 points, then counting was continued until percentages stabilized or 1,000 points had been counted. This procedure allowed counting of fewer points.

Replicate counts indicate that counting errors are usually less then 3 percent for a mineral more abundant than 30 percent. Errors are larger for minerals present in smaller amounts. Even though mafic minerals commonly make up less than 30 percent of a rock, modal estimates of total mafic minerals present are generally in close agreement between different operators. However, relative abundances of biotite and hornblende commonly show wide variation between operators where stained slabs were counted.

\section{TEXAS CREEK GRANODIORITE}

The Texas Creek Granodiorite, the oldest pluton in the map area, was named by Buddington (1929, p. 22) for excellent exposures along Texas Creek. It is exposed over an area of about $102 \mathrm{~km}^{2}$ within plate 1 and extends eastward into Canada where it is exposed over an area of about equal size (Grove, 1971). The Texas Creek Granodiorite also underlies part of the Hazelton(?) Group at shallow depths. The Hazelton(?) Group originally formed a domed roof over the pluton, but erosion removed most of the roof rocks leaving only scattered remnants and created the sinuous contact of the pluton shown on plate 1 .

The entire Texas Creek Granodiorite was affected by one or more episodes of postintrusion dynamic and thermal metamorphism. Chlorite- and epidote-filled joints and shears are closely spaced throughout the pluton. Two east-west cataclastic zones are present within the batholith, and a younger, northeast-trending cataclastic zone was formed along its eastern border. Intrusion of the Hyder Quartz Monzonite, Boundary Granodiorite, and associated younger Coast Range plutons created thermal aureoles up to $1.5 \mathrm{~km}$ wide along their contacts with the batholith.

The dominant original composition of the Texas Creek Granodiorite was hornblende-biotite granodiorite. Minor amounts of quartz diorite were present near the contacts with the Hazelton(?) Group. Potassium feldspar phenocrysts were present locally. Low-grade metamorphism has affected all the pluton, partly obliterating original textures and minerals and creating mineral assemblages typical of the greenschist facies.

Most outcrops appear to be mottled dark-green angular masses. 
Their distinctive color and shape are caused by preferential breaking along chlorite- and epidote-filled joints and shears. The joints and shears are spaced from a few centimeters to $30 \mathrm{~m}$ apart and range in width from a few millimeters to $5 \mathrm{~cm}$. The joints and shears are progressively wider and more abundant near cataclastic zones and grade indistinguishably into the general shearing in the mylonitic rocks.

\section{CATACLASTIC ROCKS}

Although zones of crushed rock occur throughout the Texas Creek Granodiorite, only two such cataclastic zones are conspicuous enough to be shown on plate 1 . Both zones trend east-west.

The northern cataclastic zone crops out in the lower part of the west fork of Texas Creek. It is about $6.5 \mathrm{~km}$ long and no more than $1,600 \mathrm{~m}$ wide. Dips of cataclastic structures are nearly vertical. Most rocks within this zone are protomylonite with subordinate amounts of mylonite. Deformation decreases gradually but irregularly away from the center of the zone, and the protomylonite merges with only locally sheared Texas Creek Granodiorite.

The southern cataclastic zone crops out in the Thumb Creek drainage and continues east across the Salmon River in the vicinity of the Riverside mine. Shears and cataclastic foliations trend nearly eastwest, parallel to the length of the zone, and have dips close to vertical. The present dimensions of the zone are about $9.7 \mathrm{~km}$ long by about $4.8 \mathrm{~km}$ wide. Originally the zone was both wider and longer by an unknown amount, but it was cut off to the east by movement on the Fish Creek fault zone and on the south and west by intrusion of the Hyder Quartz Monzonite.

Cataclasis and recrystallization increases from north to south in this zone. North of Thumb Creek protomylonite and coarse-grained mylonite predominate. These rocks grade northward into the less sheared rocks of the pluton. South of Thumb Creek fine-grained mylonite, mylonite gneiss, and ultramylonite predominate. The amount of cataclasis is variable over short distances, and lenses of unsheared granodiorite too small to map are present within the large area of cataclastic rocks. The outcrops along the Hyder-Premier road just north of Fish Creek show clearly the alternating bands of mylonite, mylonite gneiss, and narrow lenses of unsheared granodiorite, as well as the rapid changes from one rock to another.

The Lindeborg shear zone at the Riverside mine is an example of a thin zone of mylonite and ultramylonite within the wider zone of cataclastic rocks. Rocks in the Lindeborg zone are so sheared that they are difficult to distinguish from schists of the Hazelton(?) Group. Buddington (1929, p. 37) and Byers and Sainsbury (1957, p. 106) considered the Lindeborg shear zone to be one of several schist lenses 
along which subsequent movement had taken place. I believe that the Lindeborg shear zone is a zone of mylonite gneiss and ultramylonite derived from the Texas Creek Granodiorite and not a schist inclusion, on the basis of the following evidence. The cataclasites in the center of the zone grade into slightly sheared Texas Creek Granodiorite without a sharp contact. The mineralogy of the zone resembles the Texas Creek Granodiorite and not metavolcanic rocks of the Hazelton(?) Group. In the coarse-grained mylonite gneiss, augen of broken and bent potassium feldspar, quartz, and plagioclase are surrounded by a matrix of quartz, albite, and micaceous minerals. Potassium feldspar and quartz crystals the size of the augen are unknown in the Hazelton(?) Group. However, potassium feldspar phenocrysts and large quartz crystals are common in the Texas Creek Granodiorite just outside the zone. The dark fine- grained ultramylonite, which in hand specimen resembles metavolcanic rocks shows in thin section tiny crushed and strained grains of potassium feldspar, plagioclase, and quartz that indicate derivation by comminution of the Texas Creek Granodiorite.

For about $8 \mathrm{~km}$, the Hyder Quartz Monzonite-Texas Creek Granodiorite contact is parallel to the southern cataclastic zone, and Buddington (1929, p. 38) ascribed the formation of the zone to the intrusion of the Hyder Quartz Monzonite. Present mapping indicates that both east-west cataclastic zones existed before intrusion of the Hyder Quartz Monzonite and are unrelated to it for the following reasons. Although in the vicinity of the Salmon River, the contact between the two intrusions and the cataclastic zone is parallel, near Red Glacier the contact turns and truncates the zone. Elsewhere the Hyder-Texas Creek contact is sharp; cataclastic zones along the contact are absent. The cataclasite along the Hyder-Texas Creek contact was hornfelsed by intrusion of the Hyder Quartz Monzonite. This indicates prior existence of the zone, as does lack of evidence of movement within the cataclastic zone accompanying intrusion of the Hyder Quartz Monzonite. Finally, it seems unlikely that the intrusion of the Hyder Quartz Monzonite would have formed two parallel cataclastic zones separated by $4.8 \mathrm{~km}$ of less sheared rock.

PETROGRAPHIC. SUMMARY

Modal data and sample locations for the Texas Creek Granodiorite are shown in table 2 and figure 4. Metamorphism and intrusion of younger plutons affect both the accuracy of individual modes and the precision with which the modes are an estimate of the original composition of the batholith. Nearly every sample is at least partly recrystallized and cataclastic rocks are unsuitable for modal analyses. In addition, younger plutons intruded an area of unknown size for- 
TABLE 2.-Modes of Texas Creek Granodiorite

\begin{tabular}{|c|c|c|c|c|c|c|}
\hline & Sample & $\begin{array}{c}\text { Potassium } \\
\text { feldspar }\end{array}$ & Plagioclase & Quartz & $\begin{array}{c}\text { Mafic } \\
\text { minerals }\end{array}$ & Sphene \\
\hline $8 \mathrm{~S} 55 \mathrm{~A}$ & -.. & 19.6 & 48.7 & 15.7 & 16.0 & \\
\hline $8 \mathrm{~S} 40 \mathrm{~B}$ & - & 14.0 & 50.1 & 24.1 & 10.7 & 1.1 \\
\hline $8 \mathrm{~S} 109$ & - & 22.5 & 46.2 & 19.5 & 11.8 & $\ldots$ \\
\hline 8DN27 & - & 24.3 & 44.7 & 19.5 & 11.5 & $\ldots$ \\
\hline 8SJ70 & - & 5.3 & 50.5 & 24.2 & 20.0 & $\ldots$ \\
\hline $8 \mathrm{CO} 31$ & - & 14.9 & 47.9 & 20.1 & 17.1 & $-\ldots$ \\
\hline $8 \mathrm{~S} 160$ & - - & 10.2 & 49.1 & 17.2 & 23.5 & $\ldots$. \\
\hline $8 \mathrm{CO} 33$ & - & 14.8 & 46.2 & 19.0 & 20.0 & $\ldots$ \\
\hline $8 \mathrm{~S} 162$ & -..... & 15.3 & 45.6 & 22.1 & 16.7 & .3 \\
\hline $8 \mathrm{CO} 34$ & - & 15.5 & 44.3 & 19.7 & 20.3 & .3 \\
\hline $3 \mathrm{~S} 008$ & ......... & 13.5 & 43.7 & 23.3 & 19.5 & --- \\
\hline $8 D N 60$ & $-\ldots$ & 11.4 & 46.4 & 25.0 & 17.2 & -..- \\
\hline 8DN63 & - & .3 & 58.9 & 15.1 & 25.7 & $-\ldots-$ \\
\hline
\end{tabular}

merly occupied by the Texas Creek Granodiorite. For these reasons it is possible that the modal analyses might both be inaccurate and represent a biased sample population. Despite these possibilities, the modes cluster fairly tightly in the middle of the granodiorite field. While further analysis of relatively unrecrystallized Texas Creek Granodiorite might move the average composition somewhat, I doubt that it would shift into another compositional field.

In the following petrographic summary, first the original features and then the effects of subsequent metamorphism are described.

Lithology. - Originally the pluton was a medium- to coarse-grained hornblende granodiorite. Locally phenocrysts of potassium feldspar as long as $1 \mathrm{~cm}$ were present. Composition was locally quartz monzonite, and the pluton probably had a narrow border zone of quartz diorite. Ensuing intrusion and metamorphism by younger plutons affected the entire Texas Creek pluton to some degree. Most specimens appear greasy green with cloudy feldspars and indistinct grain boundaries. Chlorite- and epidote-filled joints and shears are present in nearly every specimen. Cataclasite, mylonite, and ultramylonite are present locally.

Potassium feldspar.-The present composition of potassium feldspar is microcline and microcline perthite. Originally most potassium feldspar was anhedral and interstitial with local poikilitic grains and euhedral phenocrysts to $2 \mathrm{~cm}$ across. Most grains are still fairly fresh with only a light "dusting" of nearly submicroscopic metamorphic minerals, but larger grains are crushed and strained. Many phenocrysts are now augen with milled down corners and crush trains of quartz and potassium feldspar. Potassium feldspar ranges in abundance from 0.3 to 24.3 percent. Average abundance and standard deviation are $14.0 \pm 6.4$ percent.

Plagioclase._Plagioclase was originally present as euhedral to 

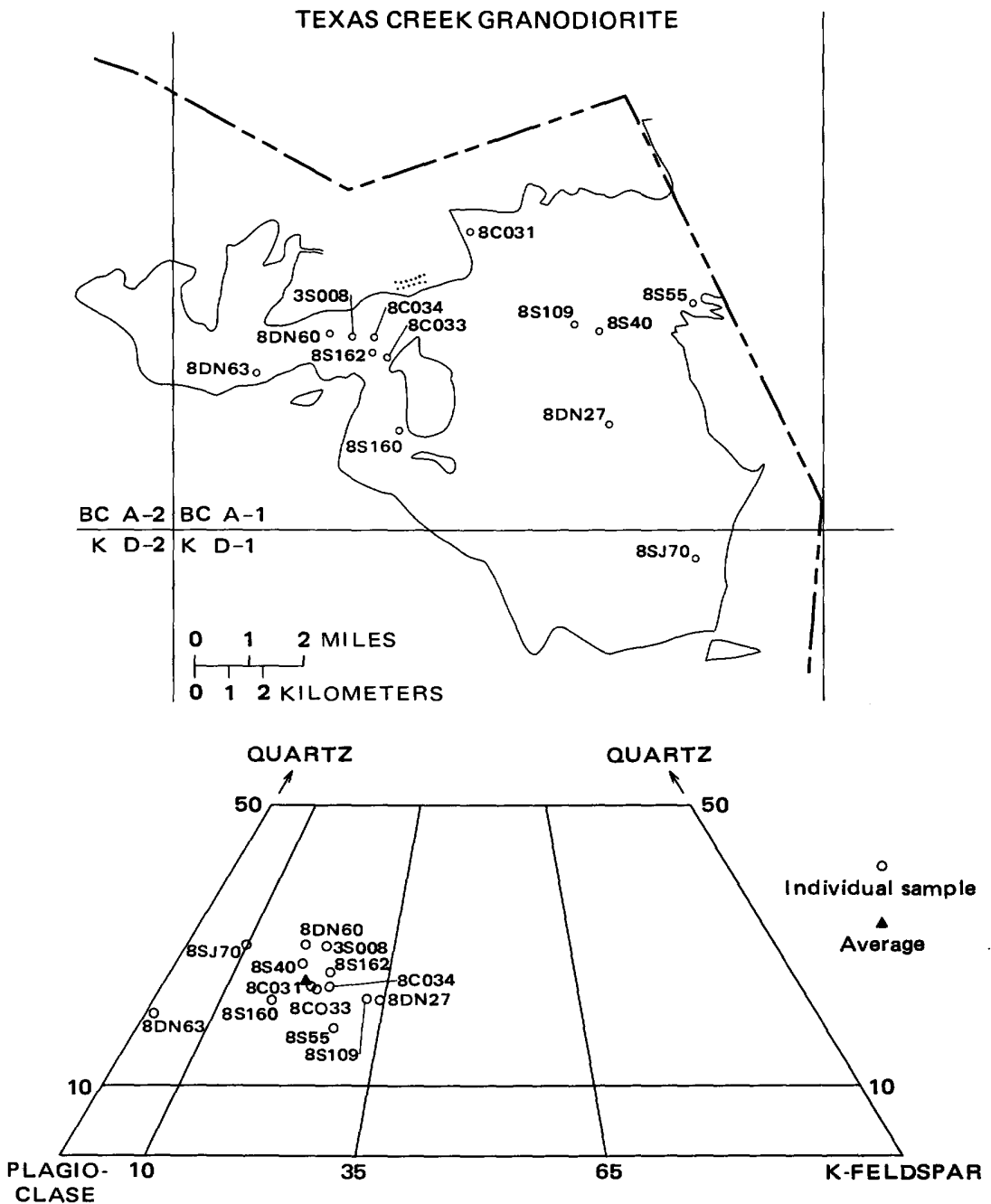

Figure 4.-Location and modal composition of samples from the Texas Creek Granodiorite. Numbers refer to samples listed in table 2.

subhedral tablets with thin multiple twin lamellae and multiple oscillatory zones. Now grains are bent and broken, corners are milled off, and many tiny new xenomorphic grains of albite are present in crush trails and groundmass. In some specimens plagioclase has completely recrystallized to masses of albite, muscovite, and clinozoisite-epidote. Plagioclase grains with original compositions are rare. Most likely the original composition was calcic-oligoclase and sodic-andesine. The present composition of all recrystallized pla- 
gioclase is albite, both in relict euhedral grains and in newly formed groundmass grains. Plagioclase ranges in abundance from 43.7 to 58.9 percent. Average abundance and standard deviation are $47.8 \pm 4.1$ percent.

Quartz.-Quartz originally occurred partly as subhedral rounded grains, approximately the same size as other original minerals, and partly as much smaller anhedral insterstitial grains. Now it is strongly strained and in many samples is broken and smeared out into fine-grained crush trails and strings. Many milled down grains are less than $0.05 \mathrm{~mm}$ in diameter. Quartz ranges in abundance from 15.1 to 25.0 percent. Average abundance and standard deviation are $20.3 \pm 3.2$ percent.

Mafic minerals.-The amount of hornblende is approximately equal to the amount of biotite. In general, mafic minerals are more recrystallized than felsic minerals. Hornblende originally formed euhedral prisms $2-10 \mathrm{~mm}$ long. The prisms were green and strongly pleochroic with $\mathrm{X}=$ straw yellow $\angle \mathrm{Y}=\mathrm{Z}=$ green with a slight bluish cast, or $\mathrm{X}=$ straw yellow $<\mathrm{Z}=$ blue green $<\mathrm{Y}=$ deep apple green. Hornblende retains its original character better than biotite and felsic minerals, except in cataclastic rocks. Recrystallization usually took place first at the grain boundaries and along fractures. Metamorphic minerals resulting from the recrystallization of hornblende include actinolite, chlorite, opaques, epidote, and apple-green biotite. Relative amount of minerals formed varies with metamorphic conditions. Biotite originally formed euhedral flakes, probably brown. In nearly every sample original biotite has been replaced by green chlorite and opaque minerals; in some samples it is impossible to tell if biotite was originally present. Mafic minerals range in abundance from 11.5 to 23.5 percent. Average abundance and standard deviation are $17.7 \pm 4.5$ percent.

Accessory minerals._Accessory minerals include sphene and opaque minerals. Sphene forms euhedral golden-yellow grains up to $2 \mathrm{~mm}$ across. Opqaue minerals are generally $1 \mathrm{~mm}$ or less in size, euhedral, and difficult to distinguish from metamorphic opaque minerals.

Metamorphic minerals._Particular mineral assemblages, compositions of metamorphic minerals, and proportions vary depending on intensity of metamorphism and whether metamorphism was lowgrade regional, cataclastic, contact, or a combination.

Muscovite (including sericite) occurs as tiny (less than $0.05 \mathrm{~mm}$ ) flakes most abundant in plagioclase. The flakes are commonly parallel (010) and (001) of the plagioclase. Muscovite and sericite are also common in microshears. 
Chlorite most commonly occurs as matted clots of tiny flakes pseudomorphous after biotite. In cataclastic rocks it is common as finely comminuted mafic streaks and scattered throughout plagioclase augen. Most chlorite has the following optical characteristics: strong pleochroism, $\mathrm{X}=\mathrm{Y}=$ apple green $>\mathrm{Z}=$ pale yellow; anomalous blue extinction and a birefringence of about 0.003 .

Epidote-clinozoisite is common in poorly formed xenomorphic nonoptically continuous small aggregates. Individual crystals are usually less than $0.05 \mathrm{~mm}$, although a few grains as large as $0.25 \mathrm{~mm}$ are found, especially in fractures. This mineral is most common in the granulated matrix of cataclasites and elsewhere as a fracture filling. Composition varies and roughly depends on the amount of metamorphism. Clinozoisite is present in the relatively low grade rocks of the headwaters of the West Fork of Texas Creek. Elsewhere, strongly pleochroic varieties (from nearly clear to intense lemon yellow) with high birefringence (up to 0.04) prevail, indicating high $\mathrm{Fe}^{+3}$ contents.

Opaque minerals are a widespread but not abundant constituent. Most grains are subidiomorphic and less than $0.05 \mathrm{~mm}$, although they range in size from nearly undiscernible dust-sized grains to $0.1 \mathrm{~mm}$. Opaque minerals occur most frequently with chlorite in clots pseudomorphous after original mafic minerals.

Calcite is not a widely occurring mineral. It is most common as xenomorphic grains in cross fractures (as wide as $1 \mathrm{~mm}$ ) and in calcite-rich crushed intergranular matrix. It also occurs as individual crystals scattered throughout the rocks and in microfractures in potassium feldspar.

Sphene is not a common mineral. It typically forms tiny clots and short strings in chlorite pseudomorphs after biotite. Most grains are less than $0.05 \mathrm{~mm}$ in diameter.

Actinolite is not a common mineral. It is mostly confined to the contact zone with Hyder Quartz Monzonite. It forms narrow fringes on hornblende crystals and microscopic needles in plagioclase grains.

Characteristic features. - The characteristic features of this pluton are (1) the nearly ubiquitous slight to strong metamorphism, (2) abundant chlorite- and epidote-filled joints and shears, (3) local cataclastic zones, (4) recrystallization of nearly every specimen to some degree with an overall dull-greenish cast, (5) cloudy plagioclase, and (6) chlorite clots replacing biotite and fuzzy crystal boundaries due to incipient recrystallization.

\section{AGE}

The Texas Creek Granodiorite is one of the oldest plutons in the Hyder area and probably within the entire Coast Range. It intrudes metavolcanic rocks assigned to the Hazelton(?) Group that are unfos- 
siliferous in the Hyder-Stewart area. Within the area shown on plate 1 , the Texas Creek Granodiorite is intruded by the 45-50-m.y.-old Hyder Quartz Monzonite and the Boundary Granodiorite. Its age relative to other plutons (e.g., schlieren granodiorite), which are also intruded by the $45-50-\mathrm{m}$.y.-suite of plutons, is unknown.

Ages determined by the potassium-argon method on biotite and hornblende mineral separates from two samples gave discordant ages in each case. Data pertinent to the age determinations are shown in the following table:

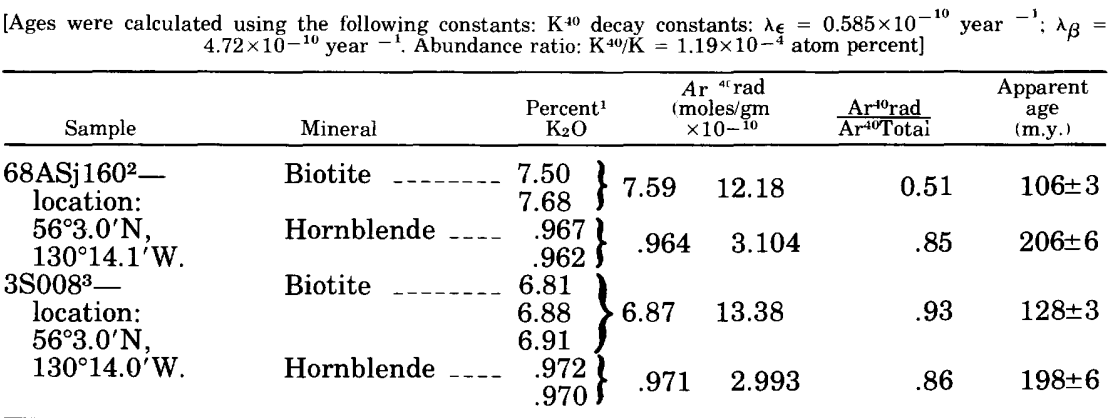

${ }^{1}$ Potassium analyses were done by Lois Schlocker using an I.L. frame photometer with a lithium internal standard.

${ }^{2}$ Argon analyses and age calculation by Jarel von Essen.

${ }^{3}$ Argon analyses and age calculation by James G. Smith.

The discordant ages and recrystallization are thought to be a result of pervasive low-grade metamorphism that affected the Texas Creek Granodiorite and the Hazelton(?) Group. Both samples were collected beyond the contact metamorphic zone caused by the intrusion of the middle Tertiary plutons, at least that part of the zone where hornfelsic recrystallization is visible in thin section.

Both hand specimens have a hypidiomorphic granular texture and prominent hornblende crystals as long as $1 \mathrm{~cm}$. Chlorite-coated joints are present, although not abundant. Plagioclase is cloudy and borders of biotite and hornblende crystals are indistinct. Most of the biotite is chloritized, and a triangular network of opaque needles is present in nearly every grain. All plagioclase is now albite, although original zoning is indicated by discontinuous but concentric rings of clinozoisite, muscovite, and tremolite.

Laboratory studies and studies of the Sierra Nevada batholith have shown that in reheated igneous rocks hornblende retains argon better than does biotite. Where potassium-argon ages of plutonic rocks are partly reset by reheating, an apparent hornblende age is generally closer than an apparent biotite age to the age of intrusion (Evernden and Kistler, 1970; Hanson and Gast, 1967). Thus a hornblende age of about 200 m.y. for the Texas Creek batholith is probably closer to the age of emplacement than are the biotite ages. 
Even so, the hornblende ages are minimum ages, and the Texas Creek Granodiorite may well be older than 206 m.y.

An age of about 200 m.y. suggests that the Texas Creek batholith was intruded in the Late Triassic or Early Jurassic, which is older than either Buddington (1929, p. 14) or Grove (1971, p. 35) suggested and older than the Early to Late Jurassic age of the fossiliferous Hazelton Group in its type area at Hazelton, British Columbia (Richards, 1974, p. 35).

\section{SCHLIEREN GRANODIORITE}

Schlieren granodiorite is located in the extreme southeast corner of the Ketchikan D-1 quadrangle and extends southeastward into the Ketchikan D-2 and C-2 quadrangles. It is known to underlie at least $65 \mathrm{~km}^{2}$, but its full extent is largely unknown.

Outcrops of schlieren granodiorite are massive and smooth where glacially polished and blocky, deeply weathered, and scarce at lower elevations where covered by vegetation. Outcrops weather to a uniform medium gray that cannot be distinguished at a distance from the color of other granitic units in spite of the distinctive planar features of this pluton.

The schlieren granodiorite is unlike the younger, massive, generally unfoliated plutons that have intruded it. Internal planar and linear structures and inhomogeneities are present everywhere, although exact patterns of internal structure are unknown. From the outcrops examined, the pluton resembles the autochthonous plutons or tails of para-autochthonous plutons described by Hutchison (1970, p. 385-386) in the Prince Rupert area $80 \mathrm{~km}$ to the south.

The most conspicuous feature of the pluton, and the one from which it takes its name, are the ubiquitous commonly contorted elongate dark streaks or schlieren (Mehnert, 1968, p. 39). These irregular bands, alternately richer and poorer in dark mafic minerals, swirl across outcrops, thicken and thin, and in distances that are measured in meters or millimeters blend into surrounding layers. Some schlieren were traced back into trains of dark blocky inclusions, others have a core that is vaguely schistose, but most schlieren are so transformed that their origin as stretched and partly digested metamorphic inclusions can only be guessed.

Other dark inclusions range from nearly absent to abundant. They are mostly gneiss and amphibolite that have retained their metamorphic layering and are composed of fine-grained biotite, hornblende, and plagioclase. The inclusions have sharp borders and appear to float parallel to the general foliation like long flat rafts surrounded by swirled granodiorite. The larger inclusions are usually stretched, twisted, bent, or broken. They commonly taper into trains of small elongate blocks with diffuse borders. Along strike, individual blocks become more ghostlike and finally lose their identity entirely 
as they blend imperceptibly into schlieric streaks.

Another distinctive characteristic of the pluton is its inhomogeneity at all scales from outcrop to thin section. Locally the pluton may be foliated, irregularly banded, genissose, migmatitic, or exhibit combinations of more than one such feature in a small area. While an average foliation can be estimated for an outcrop, in detail the planar elements vary considerably from wavy to swirled.

Potassium feldspar phenocrysts are present locally but are never abundant. Their long axes are alined in the foliation, and schlieren and banding are deformed around them.

In addition to the dark inclusions described above, random areas of migmatite are scattered throughout the pluton. Typically, schlieric to gneissose granodiorite swirls around rotated blocks with the same composition and texture. Borders between the two are sharp. However, individual blocks rarely have matching borders with their neighbors.

The swirled schlieren, the mafic inclusions, and the inhomogeneity of the pluton all suggest plastic flow of a viscous, only partly mobilized migmatitic magma. Locally, shear rates may have been too high to be taken up by flow alone, and the rock broke producing areas of migmatite.

\section{PETROGRAPHIC SUMMARY}

Table 3 and figure 5 show modal data and sample locations for specimens from the schlieren granodiorite. The modal plot shows a rather wide scatter over the granodiorite and quartz monzonite fields, but most samples, and the average composition lie in the granodiorite field. At least part of the scatter is due to the difficulty of collecting samples that are truly representative of outcrops, because of variation within the pluton.

TABLE 3.-Modes of schlieren granodiorite pluton

\begin{tabular}{|c|c|c|c|c|c|c|}
\hline & Sample & $\begin{array}{c}\text { Potassium } \\
\text { feldspar }\end{array}$ & Plagioclase & Quartz & $\begin{array}{c}\text { Mafic } \\
\text { minerals }\end{array}$ & Sphene \\
\hline $2 \mathrm{C} 104$ & -... & 16.7 & 56.0 & 15.6 & 11.4 & 0.3 \\
\hline $8 \mathrm{~S} 189$ & --- & 16.7 & 53.2 & 18.5 & 11.4 & .2 \\
\hline $2 \mathrm{~B} 316$ & -_-_-_-_-_. & 23.2 & 40.6 & 32.2 & 4.0 & \\
\hline 3E110 & -.. & 24.0 & 33.6 & 32.5 & 9.7 & .2 \\
\hline $8 \mathrm{DN} 87$ & - & 30.4 & 39.5 & 21.1 & 9.0 & \\
\hline $3 \mathrm{E} 112$ & & 40.8 & 31.0 & 22.7 & 5.3 & .2 \\
\hline $8 \mathrm{CO} 10$ & 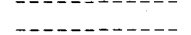 & 12.8 & 48.3 & 22.2 & 15.7 & 1.0 \\
\hline $8 \mathrm{CO} 10$ & $\ldots-\ldots$ & 9.5 & 47.1 & 16.3 & 27.1 & --- \\
\hline $8 \mathrm{CO} 14$ & $\ldots$ & 23.6 & 44.7 & 22.8 & 8.9 & --.- \\
\hline $8 \mathrm{DN} 54$ & $-\ldots$ & 24.8 & 42.4 & 24.4 & 8.4 & $\ldots$ \\
\hline $8 \mathrm{DN} 52$ & $\ldots$ & 29.7 & 49.5 & 14.4 & 6.4 & $-\ldots$ \\
\hline $3 \mathrm{~B} 110$ & $-\ldots$ & 22.7 & 47.6 & 26.7 & 2.8 & .2 \\
\hline $8 \mathrm{CO} 18$ & -.......... & 19.3 & 52.4 & 18.7 & 9.6 & $\ldots$ \\
\hline $3 \mathrm{E} 111$ & ---- & 23.0 & 44.5 & 22.5 & 10.0 & -..- \\
\hline $3 \bar{B} 111$ & -.......... & 22.3 & 50.7 & 18.2 & 8.8 & -..- \\
\hline $2 \mathrm{~B} 353$ & - & 8.4 & 50.6 & 31.6 & 9.4 & $\ldots$ \\
\hline $2 \mathrm{~B} 353$ & - & 4.5 & 54.3 & 14.8 & 26.4 & --- \\
\hline $2 \mathrm{E} 202$ & - & 17.1 & 43.3 & 32.4 & 7.2 & -..- \\
\hline $2 \mathrm{E} 203$ & - & 15.8 & 59.2 & 16.6 & 8.4 & $-{ }_{---}$ \\
\hline
\end{tabular}



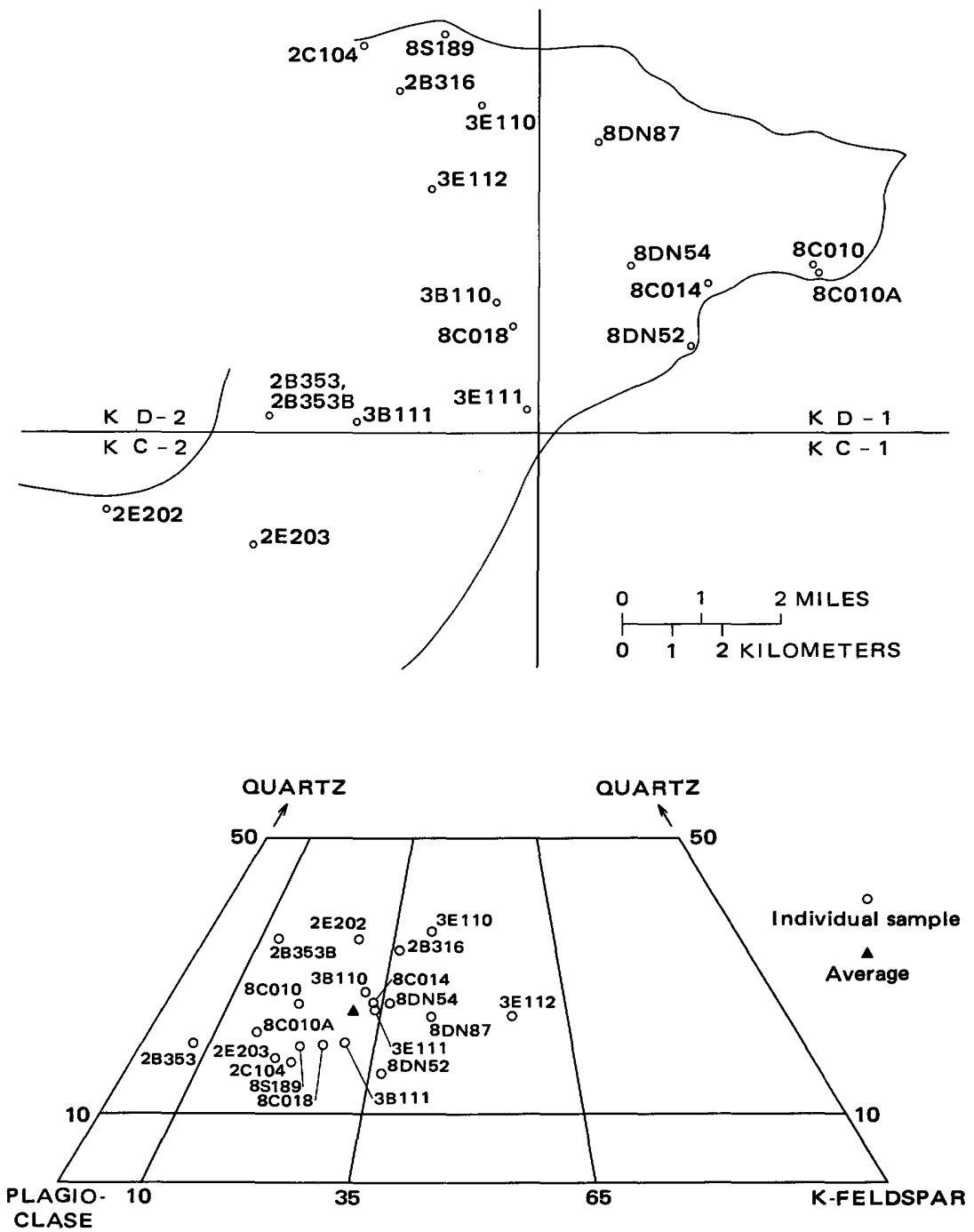

FIGURE 5.-Location and modal composition of samples from the schlieren granodiorite plution. Numbers refer to samples listed in table 3 .

The important petrographic features of the schlieren granodiorite are summarized below:

Lithology. - The pluton is a heterogeneous, foliated, locally migmatitic, banded schlieren granodiorite.

Potassium feldspar._Both orthoclase and microcline are present, 
although generally not in the same section. The mineral occurs as rare euhedral to subhedral phenocrysts $1 \mathrm{~cm}$ long and as anhedral interstitial grains. Anhedral grains are $0.5-2 \mathrm{~mm}$ across in bands rich in mafic minerals $1-5 \mathrm{~mm}$ in bands rich in feldspar. Some potassium feldspar grains are slightly crushed or strained. Potassium feldspar ranges in abundance from 4.5 to 40.8 percent. Average abundance and standard deviation are $20.3 \pm 8.5$ percent.

Plagioclase.-Plagioclase forms subhedral to anhedral stubby equant grains. Most grain boundaries are straight. Most plagioclase grains have several multiple twins per grain, although there are no complex twins. Zoning is absent or weak (no greater than 3-5 percent variation in An content). Where zoning is present, there are no more than four oscillatory zones with diffuse boundaries per grain. Grains are commonly reversely zoned. In some samples twin lamellae are bent owing to deformation of the rock. Grains range in size from $2 \mathrm{~mm}$ (mafic layers) to $5 \mathrm{~mm}$ (felsic layers). The range in composition among all samples is $\mathrm{An}_{25}$ to $\mathrm{An}_{35}$; the maximum in any one sample is about 5 percent. Plagioclase ranges in abundance from 31.0 to 59.2 percent. Average abundance and standard deviation are $46.8 \pm 7.3$ percent.

Quartz.-Quartz forms anhedral interstitial strained grains that generally have convex grain boundaries. In severely deformed rock, quartz forms small lenses with long axes parallel to foliation. Grains range in size from 0.5 to $5 \mathrm{~mm}$; they are smaller in mafic layers where quartz commonly forms inclusions in hornblende and biotite. Quartz ranges in abundance from 14.4 to 32.5 percent. Average abundance and standard deviation are $22.3 \pm 6.2$ percent.

Mafic minerals. - Hornblende is present in much greater amounts than biotite. Mafic grains have long dimensions parallel to foliation. Biotite forms subhedral to anhedral skeletal grains. The maximum size is about $1 \mathrm{~mm}$. Grains are strongly pleochroic with $\mathrm{X}=$ pale yellow, $\mathrm{Y}=\mathrm{Z}=$ dark olive brown. Hornblende forms anhedral elongate grains that are skeletal or subpoikilitic. The maximum size is about $1 \mathrm{~mm}$. Grains are strongly pleochroic with $\mathrm{Y}>\mathrm{Z}>\mathrm{X}, \mathrm{X}=$ pale yellow, $\mathrm{Y}=$ deep olive green, $\mathrm{Z}=$ deep blue green. Mafic minerals range in abundance from 2.8 to 27.1 percent. Average abundance and standard deviation are $10.6 \pm 6.3$ percent.

Accessory minerals.-Ubiquitous accessory minerals include sphene, opaque grains, and apatite. Epidote is present locally. Sphene forms euhedral to subhedral golden-yellow crystals 0.25 to $1 \mathrm{~mm}$ across. It is scarce and is more commonly seen in thin sections than hand specimens. Opaque minerals form scarce subhedral grains, some of which have rims of sphene up to $0.75 \mathrm{~mm}$ in maximum dimension. Apatite forms scarce subhedral grains as large as $0.25 \mathrm{~mm}$. 
These grains are commonly associated with biotite either as inclusions or along margins. Epidote is present in samples that show strong effects of crushing. It forms scarce anhedral but equant grains.

Grain size.-Grain size varies from sample to sample and within individual hand specimens. Most samples are fine or medium grained. Felsic layers have larger grains than mafic layers in the same specimen.

Texture.-Common textures are foliated, schlieric, regularly to irregularly banded, inequigranular, and allotriomorphic.

Characteristic features. - Characteristic features are (1) irregular, bent, twisted, and discontinuous diffuse layers (schlieren) and (2) scarce potassium feldspar phenocrysts, which have their long axes oriented within the plane of the foliation.

\section{AGE}

The schlieren granodiorite is intruded by the Hyder Quartz Monzonite and the Davis River pluton. Potassium-argon dating of samples from the Hyder and Davis River plutons suggests that they were emplaced between 45 and 55 m.y. ago. These ages agree with radiometric dates of rocks from the Coast Range batholithic complex of British Columbia summarized by Hutchison (1970, p. 397). In the Prince Rupert-Skeena area, plutons in the eastern part of the Coast Range batholithic complex were emplaced later than those to the west, during a period of intrusion that extended from Cretaceous to middle Eocene. The available evidence indicates that the schlieren granodiorite is older than middle Eocene and probably no older than Early Cretaceous, but a more precise age of formation within that 90-m.y. span is unknown. It is, therefore, considered Cretaceous or early Tertiary.

\section{DAVIS RIVER PLUTON}

The Davis River pluton is exposed over $25 \mathrm{~km}^{2}$ within the area of plate 1. South of the map area the pluton expands in outcrop area and underlies much of the Ketchikan $\mathrm{C}-1$ and $\mathrm{C}-2$ quadrangles, but its full extent is unknown. The pluton is named for the Davis River, which cuts through it and empties into Portland Canal about $1.6 \mathrm{~km}$ north of Verdure Point in the Ketchikan C-1 quadrangle.

Outcrops of the pluton are smooth and massive where glacially polished and weather to a uniform gray. The best exposures are along the shores of Portland Canal and on ridges above timberline. At close range outcrops are distinctive owing to the large potassium feldspar phenocrysts. However, at distances greater than a few meters, outcrops cannot be distinguished from those of other intrusive units.

Most of the pluton is composed of porphyritic coarse-grained biotite-hornblende granodiorite. Euhedral phenocrysts of potassium 
feldspar as large as $4 \mathrm{~cm}$ are a characteristic feature. Visual estimates indicate that they rarely constitute more than 5 percent of the rock, although at a glance they appear more abundant. However, phenocryst concentration locally may rise to $30-40$ percent in irregular zones, which average only a few tens of square meters and are widely separated. Subhedral plagioclase, quartz, and interstitial biotite, hornblende, and minor microcline form the groundmass. The mafic minerals, and less commonly quartz and feldspar, define a weak foliation.

\section{PETROGRAPHIC SUMMARY}

Modal data and sample locations for specimens from the Davis River pluton are shown in table 4 and figure 6. Potassium feldspar phenocrysts were not included in the modes because slabs were too small to contain representative numbers of phenocrysts. Field estimates indicate that 5-10 percent phenocrysts are typical. Correction of modal data by this amount still leaves the average composition and a majority of individual points within the granodiorite field. Important petrographic features of the Davis River pluton are summarized below.

Lithology. - The pluton is a homogeneous porphyritic granodiorite with minor quartz diorite and quartz monzonite.

Potassium feldspar.-Microcline predominates, although orthoclase is the potassium feldspar in a few samples. Potassium feldspar occurs as euhedral twinned phenocrysts as large as $5 \mathrm{~cm}$ and as anhedral interstitial grains $0.25-5 \mathrm{~mm}$ across. Phenocrysts constitute 5-10 percent of outcrops from visual estimate. The corners of phenocrysts are rounded, as if they were milled off. Rings of inclusions are common in phenocrysts. Potassium feldspar in the groundmass (phenocrysts were not counted) ranges in abundance from 1.6 to 22.0 percent. Average abundance and standard deviation are $11.1 \pm 6.7$ percent.

TABLE 4.-Modes of Davis River pluton

[Modes are for groundmasses and do not include phenocrysts]

\begin{tabular}{|c|c|c|c|c|c|}
\hline Sample & $\begin{array}{l}\text { Potassium } \\
\text { feldspar }\end{array}$ & Plagioclase & Quartz & $\underset{\text { mafic }}{\text { Mals }}$ & Sphene \\
\hline 8DN58 & 7.1 & 51.0 & 29.5 & 11.9 & 0.5 \\
\hline $3 \mathrm{~S} 038$ & 1.6 & 60.4 & 14.2 & 23.7 & .1 \\
\hline $8 \mathrm{DN} 50$ & 20.8 & 48.3 & 21.8 & 9.1 & $\ldots \ldots$ \\
\hline $8 \mathrm{CO} 13$ & 22.0 & 40.4 & 32.0 & 5.6 & -.-- \\
\hline 8DN59 & 6.7 & 53.2 & 26.4 & 13.5 & .2 \\
\hline 8DN46 & 9.5 & 50.3 & 26.5 & 13.7 & $\ldots$ \\
\hline 8SJ84 & 7.5 & 57.5 & 22.2 & 12.8 & $\ldots$ \\
\hline 8SI96 & 4.2 & 55.9 & 25.7 & 13.9 & .3 \\
\hline 8SJ86 & 13.3 & 48.0 & 29.8 & 8.8 & .1 \\
\hline 8SJ88 & 11.6 & 50.6 & 27.2 & 10.6 & $\ldots$ \\
\hline 8SJ89 & 17.1 & 49.4 & 26.3 & 7.2 & $\ldots$ \\
\hline
\end{tabular}



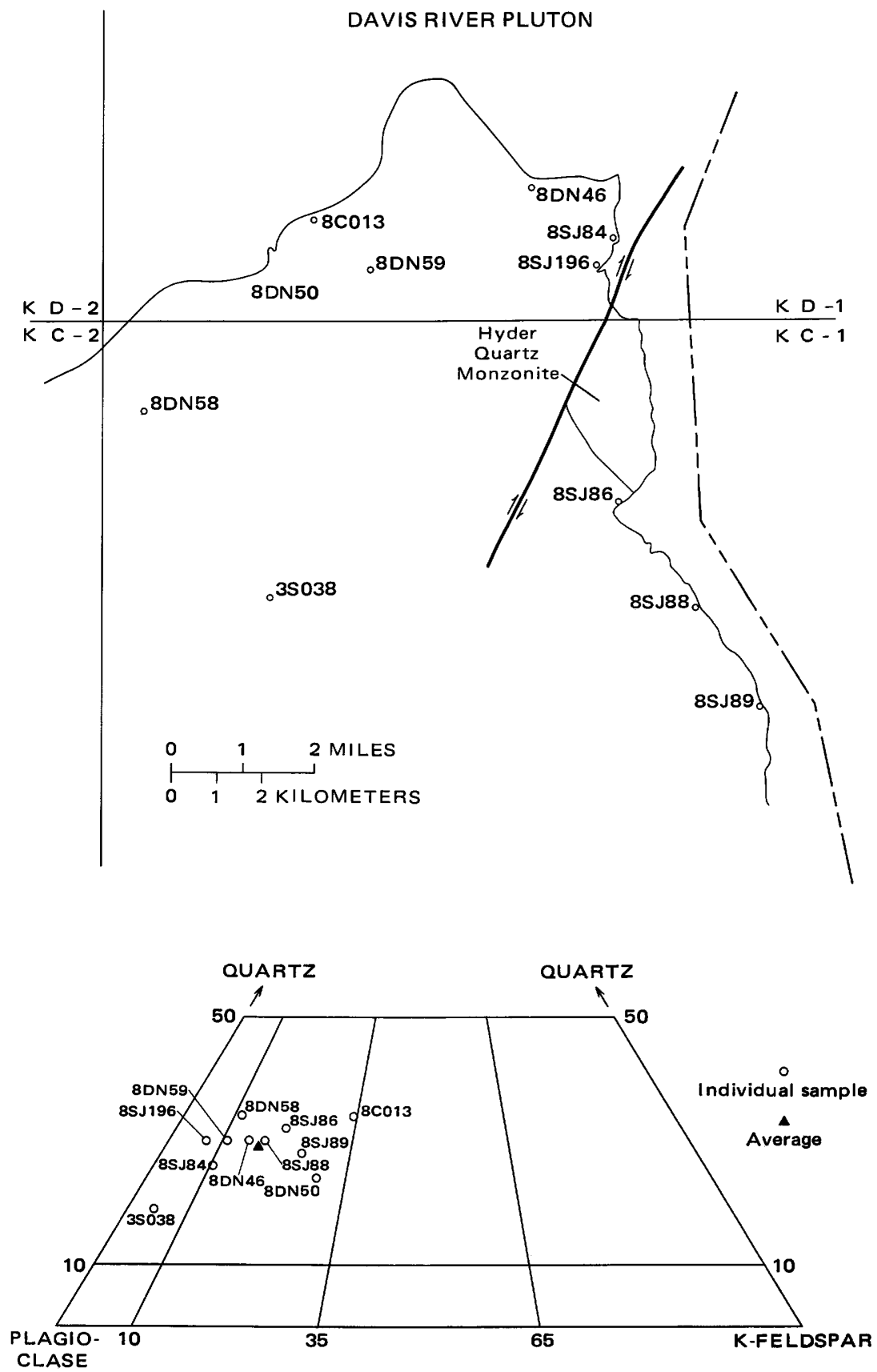

FIGURE 6.-Location and modal composition of samples from the Davis River pluton. Modes are for groundmasses and do not include phenocrysts. Numbers refer to samples listed in table 4. 
Plagioclase. - The crystals are dominantly subhedral with rounded corners. Many grains indent one another. Multiple twins are common, as are bent twin lamellae. Zoning is common (10-15 zones), and many grains have rounded faintly zones cores. Grains range in size from 2 to $5 \mathrm{~mm}$. The maximum range in composition for all samples is from $\mathrm{An}_{35}$ (core) to $\mathrm{An}_{20}$ (rim). The average range in any one grain is about 10 percent An. Plagioclase ranges in abundance from 40.4 to 60.4 percent. Average abundance and standard deviation are $51.4 \pm 5.4$ percent.

Quartz.-Quartz forms anhedral strongly strained grains. Many grain boundaries are crenulated. Thin bands of granulated quartz are common between closely spaced plagioclase grains. Locally larger quartz grains are augen shaped. Quartz ranges in size from nearly submicroscropic to $7 \mathrm{~mm}$ and ranges in abundance from 14.2 to 32.0

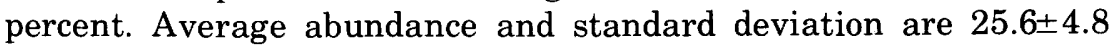
percent.

Mafic minerals. - Biotite is more common than hornblende. Mafic minerals are interstitial and finer grained than other minerals. Biotite forms subhedral flakes that are commonly bent. Maximum size is about $4 \mathrm{~mm}$. Grains are strongly pleochroic with $\mathrm{X}=$ light straw yellow, $\mathrm{Y}=\mathrm{Z}=$ dark olive green. There is minor alteration to chlorite. Hornblende forms subhedral stubby strongly pleochroic prisms $3 \mathrm{~mm}$ in maximum length. The pleochroic scheme is $\mathrm{Y}>\mathrm{Z}>\mathrm{X}, \mathrm{X}=$ light straw yellow, $\mathrm{Y}=$ nearly opaque emerald green, $\mathrm{Z}=$ deep blue green. The mafic minerals range in abundance from 5.6 to 13.9 percent. Average abundance and standard deviation are $11.9 \pm 4.8$ percent.

Accessory minerals.-Ubiquitous accessory minerals include sphene, opaque grains, and apatite. Allanite is present locally. Sphene is a common accessory mineral which is visible in many hand specimens. Crystals are euhedral to subhedral and less than $2 \mathrm{~mm}$ long. Opaque minerals are subhedral and $0.5-1 \mathrm{~mm}$ long. Apatite forms scarce generally euhedral colorless grains. Allanite occurs as scarce deep-honey-colored anhedral grains.

Grain size.-Potassium feldspar phenocrysts range from $1 \mathrm{~cm}$ to $5 \mathrm{~cm}$. Felsic groundmass minerals average about $5 \mathrm{~mm}$, and mafic groundmass minerals average about $2 \mathrm{~mm}$.

Texture.-Textures of most samples are porphyritic, with a hypidiomorphic granular groundmass. In general, mafic minerals are finer grained than felsic or interstitial grains.

Characteristic features. - Characteristic features are (1) large phenocrysts of potassium feldspar, (2) interstitial mafic minerals, (3) rounded phenocrysts, (4) bent plagioclase and biotite grains, strongly strained quartz, and other evidence of mild crushing, and (5) rounded calcic cores in plagioclase grains. 
AGE

The Davis River pluton intrudes the schlieren granodiorite and is in turn intruded by the Hyder Quartz Monzonite. Hornblende and biotite from a single sample were dated by the potassium-argon method. The ages on the two minerals are discordant by about 20 percent, but the 52.5-m.y.- (early Eocene) date of the hornblende is a minimum age of intrusion. The cause of the discordance is not known but may be a result of reheating by a younger thermal event or intrusion of the Hyder Quartz Monzonite. Data on which the age determination was based are shown in the following table:

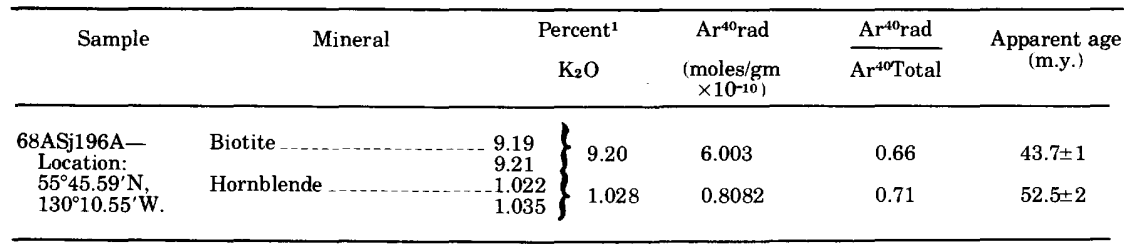

${ }^{1}$ Potassium and argon analyses done by Lois Schlocker and Jarel von Essen, respectively. Methods and decay constants are the same as those used to calculate the age of the Texas Creek Granodiorite.

\section{HYDER QUARTZ MONZONITE}

The Hyder Quartz Monzonite is a large pluton that extends beyond the mapped area westward into the Ketchikan D-2 quadrangle and eastward across Portland Canal into British Columbia (Grove, 1971). The pluton has a generally elliptical outline with the long axis trending northwest-southeast. Within the map area the pluton underlies about $400 \mathrm{~km}^{2}$. If adjacent areas outside the map area are included, the Hyder Quartz Monzonite crops out over more than $520 \mathrm{~km}^{2}$.

The Hyder Quartz Monzonite was named by Buddington (1929, p. 30) for excellent exposures of quartz monzonite at the town of Hyder, Alaska, at the head of Portland Canal. The areas accessible to Buddington, and from which he collected samples to classify the pluton, coincide with areas that modern helicopter-assisted mapping has shown to be quartz monzonite phases of a dominantly granodiorite pluton (pl. 1). Just how far to the south and west Buddington intended to recognize the Hyder Quartz Monzonite is unclear. His geologic sketch map (Buddington, 1929, pl. 3) includes the Hyder in a granodiorite that extends from Hyder and the Portland Canal on the east to Behm Canal on the west. This granodiorite is mapped in this report as the Davis River pluton and the schlieren granodiorite pluton. However, he states (p. 30) that south of Hyder "the Hyder quartz monzonite passes into the granodiorite or interbanded granodiorite and quartz monzonite that forms most of the core of the Coast Range batholith," but there is no further discussion of the location or nature of this contact. 
Present mapping on both sides of the international boundary shows that most of the Hyder Quartz Monzonite is composed of coarsegrained biotite-hornblende granodiorite with lesser amounts of coarse-grained biotite quartz monzonite and minor alaskite. Inclusions, xenoliths, and schlieren are rare; joints, both feldspathized and fresh, are common. Aplite and pegmatite dikes are also common, more so in the quartz monzonite phases than in the granodiorite phases.

Outcrops of Hyder Quartz Monzonite are massive and smoothly rounded below about $1,830 \mathrm{~m}$, the upper limit of overriding Pleistocene glaciation. Peaks and ridges that rose above the ice remain as massive angular light-colored peaks and aretes.

Hand specimens of fresh samples are pinkish or dull white. A variety of coarse-grained hypidomorphic granular textures is present. Grain size tends to be smaller in more mafic samples. Locally, in quartz monzonite phases, potassium feldspar phenocrysts occur, but they are neither so large nor so abundant as in the adjoining Davis River pluton.

In most samples, mafic minerals and potassium feldspar are interstitial and subhedral to anhedral, suggesting late crystallization. Plagioclase is euhedral, and quartz forms rounded subhedral grains, one of the characteristics of this pluton. The shape of these minerals suggests that they crystallized early.

Few traverses across contacts between granodiorite and quartz monzonite were made. However, available observations suggest renewed upward movement of the quartz monzonite phase centered around Soule Glacier in the center of the pluton after consolidation of the granodiorite outer phase. The massive unfoliated granodiorite and quartz monzonite phases are separated by a zone $0.8-1.6 \mathrm{~km}$ wide. Rocks within the zone are moderately to strongly foliated and marked by conspicuous schlieren. The foliation dips moderately outward away from the core of the pluton.

\section{PETROGRAPHIC SUMMARY}

Modal data and sample locations for the Hyder Quartz Monzonite are shown in table 5 and figure 7. The modal plot (fig. 7) shows a

TABLE 5.-Modes of Hyder Quartz Monzonite

\begin{tabular}{|c|c|c|c|c|c|c|}
\hline & Sample & $\begin{array}{c}\text { Potassium } \\
\text { feldspar }\end{array}$ & Plagioclase & Quartz & $\begin{array}{c}\text { Mafic } \\
\text { minerals }\end{array}$ & Sphene \\
\hline $8 \mathrm{CO} 06$ & & 22.1 & 42.1 & 27.0 & 8.8 & \\
\hline $8 \mathrm{CO07}$ & - & 16.9 & 48.4 & 20.3 & 14.4 & -..- \\
\hline $8 \mathrm{CO} 08$ & - & 39.3 & 31.1 & 28.6 & 1.0 & \\
\hline $8 \mathrm{CO} 09$ & ------ & 18.4 & 45.9 & 20.0 & 15.6 & 0.1 \\
\hline $8 \mathrm{CO} 16$ & - & 3.1 & 59.7 & 17.7 & 19.5 & $\ldots$ \\
\hline $8 \mathrm{DN} 12$ & - & 19.1 & 43.9 & 27.7 & 9.3 & $\ldots$ \\
\hline 8DN13 & ---1 & 35.6 & 29.8 & 32.9 & 1.7 & ---- \\
\hline $8 \mathrm{DN} 14$ & - & 20.7 & 42.6 & 24.8 & 11.9 & $\ldots$ \\
\hline
\end{tabular}


KETCHIKAN D-1 AND BRADFIELD CANAL A-1 QUADRANGLES

TABLE 5.-Modes of Hyder Quartz Monzonite-Continued

\begin{tabular}{|c|c|c|c|c|c|c|}
\hline & Sample & $\begin{array}{l}\text { Potassium } \\
\text { Feldspar }\end{array}$ & Plagioclase & Quartz & $\begin{array}{c}\text { Mafic } \\
\text { minerals }\end{array}$ & Sphene \\
\hline 8DN15 & & 27.3 & 36.0 & 33.2 & 3.5 & \\
\hline $8 \mathrm{DN} 16$ & -- & 17.0 & 43.7 & 26.3 & 12.7 & .3 \\
\hline $8 \mathrm{DN} 17$ & -.. & 14.6 & 46.6 & 26.1 & 12.7 & --.- \\
\hline 8DN18 & & 23.3 & 43.4 & 22.9 & 10.4 & --.- \\
\hline 8DN20 & --. & 24.8 & 44.4 & 22.8 & 8.0 & -..- \\
\hline $8 \mathrm{DN} 23$ & & 32.7 & 35.1 & 29.0 & 3.2 & -..- \\
\hline 8DN44 & $\ldots$ & 13.5 & 50.1 & 23.2 & 13.0 & .2 \\
\hline $8 \mathrm{DN} 47$ & & 21.5 & 43.3 & 25.7 & 9.5 & -..- \\
\hline 8DN48 & $\ldots$ & 19.7 & 47.0 & 18.0 & 15.3 & -..-- \\
\hline 8DN49 & & 28.8 & 47.0 & 19.3 & 4.9 & --.- \\
\hline $8 \mathrm{DN} 80$ & $-\cdots$ & 26.2 & 42.9 & 19.5 & 11.4 & -.-- \\
\hline 8DN82 &.- & 17.0 & 46.5 & 23.6 & 12.9 & ---- \\
\hline 8DN84 & $\ldots$ & 21.0 & 46.1 & 25.6 & 7.3 & $\ldots$ \\
\hline $8 \mathrm{DN} 85$ & - & 31.1 & 34.5 & 21.4 & 13.0 & $-\ldots$ \\
\hline 8SJ39 & $\ldots$ & 19.0 & 45.7 & 22.3 & 12.7 & .3 \\
\hline 8SJ52 & -- & 23.8 & 46.0 & 23.7 & 6.5 & \\
\hline 8SJ53 & $-\cdots$ & 25.2 & 42.5 & 26.1 & 6.0 & .2 \\
\hline 8SJ54 & -.- & 26.0 & 43.8 & 24.3 & 5.9 & \\
\hline 8SJ74 & -..- & 16.2 & 51.7 & 19.7 & 12.3 & .1 \\
\hline 8SJ75 & $\ldots$ & 19.6 & 44.6 & 22.1 & 13.7 & $\ldots$ \\
\hline 8SJ76 & $\ldots$ & 21.8 & 43.7 & 23.7 & 10.8 & -.-- \\
\hline 8SJ77 & --- & 22.8 & 46.6 & 22.2 & 8.4 & ---- \\
\hline 8SJ78 & $-\ldots$ & 29.2 & 45.3 & 15.8 & 9.7 & $\ldots$ \\
\hline 8SJ79 & $-\ldots$ & 12.2 & 53.7 & 21.0 & 13.1 & -..- \\
\hline 8SJ80 & --- & 13.0 & 53.1 & 22.0 & 11.9 & ...- \\
\hline 8SJ81 & $\ldots$ & 16.1 & 44.8 & 25.6 & 13.5 & -.-- \\
\hline 8SJ90 & $\ldots$ & 24.3 & 46.2 & 23.7 & 5.5 & .3 \\
\hline $8 \mathrm{~S} 115$ & -.. & 21.2 & 43.1 & 30.2 & 5.5 & ---- \\
\hline $8 \mathrm{~S} 116$ & $\ldots$ & 27.4 & 36.2 & 28.8 & 7.6 & --- \\
\hline $8 \mathrm{~S} 117$ & $\ldots$ & 25.8 & 37.5 & 26.4 & 10.3 & $\ldots$ \\
\hline $8 \mathrm{~S} 118$ & .... & 21.0 & 42.5 & 22.7 & 13.8 & -... \\
\hline $8 \mathrm{~S} 119$ & $\ldots$ & 14.2 & 50.4 & 24.0 & 11.4 & $\ldots$ \\
\hline $8 \mathrm{~S} 121$ & - & 22.4 & 40.5 & 23.0 & 14.1 & --.- \\
\hline $8 \mathrm{~S} 122$ & -..... & 20.5 & 42.0 & 24.5 & 13.0 & ---- \\
\hline $8 \mathrm{~S} 123$ & - & 19.5 & 38.8 & 29.7 & 12.0 & $\ldots$ \\
\hline $8 \mathrm{~S} 124$ & $\ldots$ & 24.7 & 43.3 & 23.9 & 8.1 & -..- \\
\hline $8 \mathrm{~S} 126$ & -......-. & 31.6 & 30.3 & 36.0 & 2.1 & -.-- \\
\hline $8 \mathrm{~S} 127$ & -_-_- & 19.8 & 34.0 & 40.7 & 5.5 & ---- \\
\hline $8 \mathrm{~S} 129$ & -.-- & 39.0 & 26.3 & 32.3 & 2.4 & -..- \\
\hline $8 \mathrm{~S} 165$ & - & 34.2 & 38.3 & 24.3 & 3.2 & $-\ldots$ \\
\hline $8 \mathrm{~S} 187$ & - & 16.9 & 51.0 & 22.9 & 9.1 & .1 \\
\hline $8 \mathrm{~S} 188$ & - & 10.0 & 50.3 & 16.7 & 23.0 & \\
\hline $8 \mathrm{~S} 216$ & - & 26.7 & 40.0 & 22.9 & 10.3 & .1 \\
\hline $2 \mathrm{E} 239$ & - & 23.7 & 43.3 & 26.2 & 6.8 & \\
\hline $2 \mathrm{E} 409$ & -_-_- & 9.4 & 56.3 & 17.8 & 16.0 & .5 \\
\hline $2 \mathrm{E} 410$ & - & 22.6 & 50.4 & 22.6 & 4.1 & .3 \\
\hline $2 \mathbf{E} 411$ & - & 30.1 & 47.0 & 18.3 & 4.5 & .1 \\
\hline $2 \mathrm{E} 414$ & - & 20.7 & 52.2 & 21.5 & 5.5 & .1 \\
\hline $2 \mathrm{E} 412$ & - & 28.7 & 44.5 & 21.8 & 4.8 & .2 \\
\hline $2 \mathrm{E} 416$ & - & 20.6 & 47.6 & 24.6 & 7.0 & .2 \\
\hline $2 \mathrm{E} 417$ & - & 3.6 & 56.7 & 15.7 & 24.0 & \\
\hline $2 \mathrm{~S} 088$ & - & 22.9 & 45.7 & 23.5 & 7.6 & .3 \\
\hline $2 \mathrm{~S} 126$ & - & 25.0 & 45.0 & 21.4 & 8.4 & .2 \\
\hline $2 \mathrm{~S} 127$ & - & 21.3 & 44.7 & 23.5 & 10.3 & .2 \\
\hline $2 \mathrm{~S} 128$ & --_--_- & 21.3 & 38.7 & 30.8 & 9.0 & .2 \\
\hline $2 \mathrm{~S} 129$ & - & 9.8 & 51.3 & 19.7 & 19.0 & .2 \\
\hline 3E104 & - & 21.3 & 43.1 & 28.0 & 8.0 & $-\ldots$ \\
\hline $3 \mathrm{E} 106$ & - & 11.0 & 49.9 & 21.0 & 17.8 & .3 \\
\hline $3 \mathrm{E} 113$ & - & 25.5 & 40.3 & 27.5 & 6.7 & ---- \\
\hline $3 \mathrm{E} 114$ & - & 22.1 & 44.0 & 30.2 & 3.7 & -..- \\
\hline
\end{tabular}



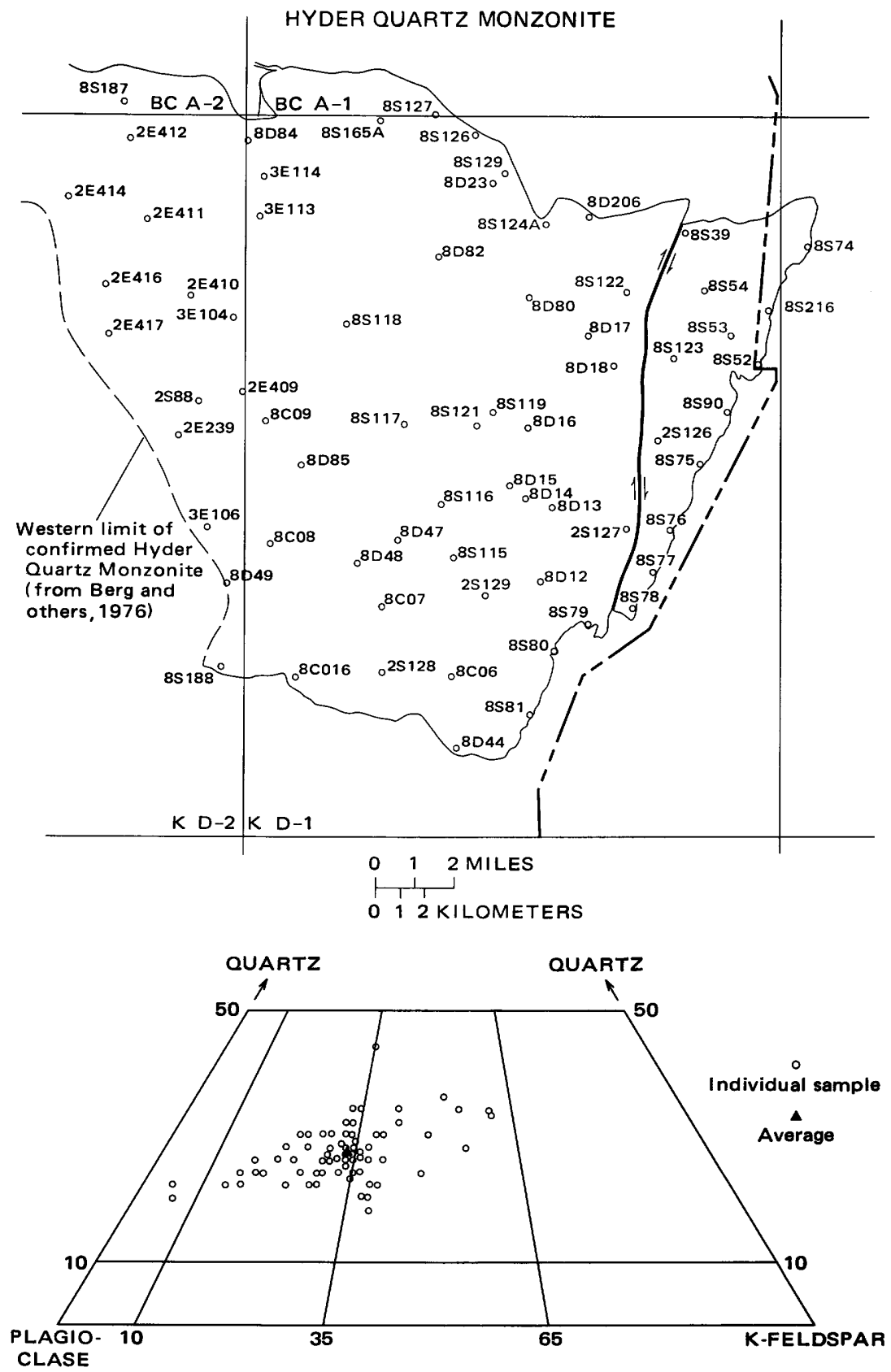

FigURE 7.-Location and modal compositon of samples from the Hyder Quartz Monzonite. Numbers refer to samples listed in table 5 . 
smooth and nearly straight trend from quartz diorite, with about 20 percent quartz, to granite. There is little scatter of modes. Despite the wide overall range in composition, most samples lie close to the dividing line between quartz monzonite and granodiorite.

The important petrographic features of the Hyder Quartz Monzonite are summaried below.

Lithology.-The pluton is dominantly granodiorite with subordinate quartz monzonite and minor alaskite.

Potassium feldspar.--Microcline and microcline perthite are present. Crystals are generally anhedral and interstitial, rarely porphyritic or poikilitic. Poikilitic overgrowths are more common in granodiorite, and single Karlsbad twins are more common in quartz monzonite. Potassium feldspar ranges in abundance from 3.1 to 39.3 percent. Average abundance and standard deviation are 21.7 \pm 7.2 percent.

Plagioclase.-Plagioclase generally occurs as euhedral tablets. Karlsbad-albite complex twins are common. Crystals are strongly zoned with 15 to 20 oscillatory zones in granodiorite samples. Zoning is more variable in quartz monzonite. Composition ranges from $\mathrm{An}_{35}$ (core) to $\mathrm{An}_{20}$ (rim) in granodiorite. Quartz monzonite phases have a wider range in composition. The extreme range is $\mathrm{An}_{45}$ (core) to $\mathrm{An}_{15}$ (rim). Plagioclase ranges in abundance from 26.3 to 59.7 percent. Average abundance and standard deviation are $44.2+6.4$ percent.

Quartz.-Quartz most commonly occurs as ovoid subhedral strained grains 5-10 mm across. Less commonly it is interstitial. It ranges in abundance from 15.7 to 40.7 percent. Average abundance and standard deviation are $24.3 \pm 4.7$ percent.

Mafic minerals.-Biotite and hornblende are present in about equal amounts in the granodiorite phases. In quartz monzonite phases, hornblende is present in much smaller amounts than biotite or is absent altogether. Biotite is euhedral in granodiorite but subhedral in quartz monzonite. In most samples biotite is brown, but in some it is green. Hornblende is euhedral in granodiorite but subhedral and skeletal in quartz monzonite. It is green in all samples. Mafic minerals and accessory minerals commonly are interstitial in quartz monzonite. The mafic minerals range in abundance from 1.0 to 24.0 percent. Average abundance and standard deviation are $9.8 \pm 4.9$ percent.

Accessory minerals.-Ubiquitous accessory minerals include sphene and opaque grains. Apatite, allanite, and zircon or xenotime are present in some samples. Sphene forms euhedral crystals that are visible in most hand specimens as tiny golden grains. Opaque minerals form euhedral or subhedral grains less than $1 \mathrm{~mm}$ across. Apatite is most common as inclusions in biotite. 
Grain size.-Grain size varies from phase to phase; in most samples it is $1-5 \mathrm{~mm}$. Few samples have grains larger than $10 \mathrm{~mm}$.

Texture.-Although variable texture is most commonly hypidiomorphic granular, inequigranular and porphyritic textures also occur.

Characteristic features. - The distinctive features of the Hyder Quartz Monzonite are (1) ovoid subhedral quartz grains, (2) golden euhedral sphene, (3) lack of xenoliths or inclusions, and (4) generally massive, unfoliated outcrops. Composition, mineralogy, texture, and grain size are variable. A more detailed study would probably reveal more phases and perhaps other intrusive units.

\section{DIKES}

Dikes of light-colored porphyritic granodiorite occur locally along the periphery of the Hyder Quartz Monzonite. Most are widely spaced, from a few meters to hundreds of meters thick, and could not be traced back into the pluton. Porphyritic granodiorite dikes are common at two localities, both in metavolcanic rocks of the Hazelton(?) Group. At one locality, near the intersection of Through and Greenpoint Glaciers, the dikes lack strong preferred orientation, and attitudes range from horizontal to vertical. Some dikes were intruded parallel to the foliation of the folded metamorphic rocks, giving the false impression that the dikes themselves were folded.

In hand specimen fresh dikes are light gray or green; deuterically altered dikes are chalky white. Intrusion of the dikes had little effect on the country rocks. Most dikes have dark devitrified chill zones a few centimeters wide. Biotite, hornblende, and strongly zoned plagioclase phenocrysts are present in nearly every specimen; quartz and potassium feldspar are less common. The mafic minerals are usually partly altered to chlorite, opaque minerals, and a minor amount of epidote. Groundmass is fine grained to microcrystalline intergrowths of quartz, potassium feldspar with or without plagioclase, and minor amounts of opaque minerals, chlorite, epidote, and sphene.

A more extensive swarm of alined porphyritic granodiorite dikes crops out between Mount Dolly and Mount Welker and can be seen from many places along the Salmon River road. Many of the dikes extend across the international boundary and can be traced back into the Hyder Quartz Monzonite in British Columbia (Grove, 1971). The general trend of the Mount Dolly dike swarm is northwest.

Dikes in the Mount Dolly area strike northwest across trends in the country rock, are subparallel, and dip steeply. They range in thickness from 1 to $370 \mathrm{~m}$; most are between 3 and $30 \mathrm{~m}$ thick. A swarm of these dikes crosses the Premier Mine road between Ninemile and the international boundary. 
AGE

Radiometric dates of about 49 and 46 m.y. for the Hyder Quartz Monzonite indicate that it was intruded during Eocene time and is one of the younger plutons of the Coast Range batholith. The age assignment is based on potassium-argon dating of biotite from two fresh samples of the pluton. The first sample was collected at the quarry on the international boundary at Hyder, and the second at the 618-m elevation on Soulé Glacier.

Data pertinent to the age determinations are shown in the following table:

\begin{tabular}{|c|c|c|c|c|c|}
\hline Sample & Mineral & $\begin{array}{c}\text { Percent }^{1} \\
\mathrm{~K}_{2} \mathrm{O}\end{array}$ & $\begin{array}{c}\text { Ar worad } \\
(\text { moles/gm } \\
\times 10-10)\end{array}$ & $\frac{\mathrm{Ar}^{40} \mathrm{rad}}{\mathrm{Ar}^{40} \mathrm{Total}^{\circ}}$ & $\begin{array}{c}\text { Apparent } \\
\text { age } \\
\text { (m.y.) }\end{array}$ \\
\hline $\begin{array}{l}\text { 68ASj52-location: } \\
\text { quarry on inter- } \\
\text { national border, } \\
55^{\circ} 54.75^{\prime} \mathrm{N} \\
130^{\circ} 0.96^{\prime} \mathrm{W} \text {. }\end{array}$ & Biotite & $\left.\begin{array}{l}8.79 \\
8.80\end{array}\right\} 8.80$ & 6.477 & 0.74 & $49.2+2$ \\
\hline $\begin{array}{l}\text { 68ADn } 47 \text {-location: } \\
\text { east margin Soulé } \\
\text { Glacier at } 618 \mathrm{~m} \text {, } \\
55^{\circ} 51.65^{\prime} \mathrm{N} \\
130^{\circ} 14.3^{\prime} \mathrm{W} \text {. }\end{array}$ & Biotite & $\left.\begin{array}{l}8.80 \\
8.82\end{array}\right\} 8.81$ & 6.073 & .68 & $46.1 \pm 1$ \\
\hline
\end{tabular}

${ }^{1}$ Potassium and argon analyses were done by Lois Schlocker and Jarel von Essen, respectively. Methods and decay constants are the same as those used to calculate the age of the Texas Creek Granodiorite.

\section{BOUNDARY GRANODIORITE}

The Boundary Granodiorite straddles the Canadian-United States border with approximately half the pluton in each country. Detailed study is hampered by the year-round cover of ice and snow over most of the pluton. Many samples studied for this report were collected from scattered nunataks, some of which have appeared from beneath the snow only in the past few years. The Boundary Granodiorite is not mapped in detail in British Columbia, but a reconnaissance map by Bacon (1955) shows the eastern contact of the Coast Range batholith within $3 \mathrm{~km}$ of the international boundary in the Bradfield Canal A-1 quadrangle. Therefore, a maximum size for the pluton would be $65 \mathrm{~km}^{2}$. More recent mapping by Grove (1971, fig 3, sheet C) suggests an even smaller outcrop area in British Columbia. Within Alaska the pluton underlies about $32 \mathrm{~km}^{2}$.

The Boundary Granodiorite was named by Buddington (1929, p. 32) for excellent exposures of granodiorite in the drainage basin of Boundary Glacier (also known as Munroe Glacier on Canadian maps). Since 1929 the glaciers have shrunk, enlarging areas of outcrop and revealing new ones.

The major part of the Boundary Granodiorite is composed of slightly inequigranular hypidiomorphic medium-grained biotite- 
hornblende granodiorite. The texture is generally uniform throughout the body. The western part of the pluton is composed, at least in part, of quartz monzonite. As much of the pluton is either in British Columbia or covered, the relation between the east and west half of the pluton is unknown. It is possible that the western part may belong to a different intrusive unit.

Owing to their recent emergence from beneath snow cover, typical outcrops of Boundary Granodiorite are massive, smooth, without vegetation, and light colored. Small fine-grained inclusions of country rock and shadowy mafic clots rich in biotite and hornblende are common. Maximum abundance of inclusions and clots is about 2-3 per square meter. The inclusions and clots are one of the characteristic features of the pluton. Both chlorite-coated joints and clean joints are common. Most joints can be traced for hundreds of meters. Most chlorite-coated joints strike northwest and dip steeply south, which is also a common attitude for aplite dikes associated with the pluton and for dikes of Boundary Granodiorite within the surrounding country rocks.

Hand specimens are generally fresh, dull white, and flecked with dark mafic grains. Tiny euhedral sphene grains can be seen in most specimens. Hand specimens of Boundary Granodiorite resemble many specimens of Hyder Quartz Monzonite at first glance, but in general the Boundary Granodiorite is finer grained, hornblende needles are better formed and more distinct, and all minerals are slightly inequigranular.

\section{PETROGRAPHIC SUMMARY}

The average mode of the Boundary Granodiorite lies well within the granodiorite field, and all samples but one lie in the granodiorite field as well (fig. 8; table 6). Although there are only a few samples, figure 8 shows that samples from the core of the pluton are richer in quartz than samples from near the border. Mafic mineral content increases slightly but evenly from the core to the border of the pluton. The inequigranular and generally medium grained texture, euhedral larger grains, and small size of the pluton suggest rapid cooling.

TABLE 6.-Modes of Boundary Granodiorite

\begin{tabular}{|c|c|c|c|c|}
\hline Sample & $\begin{array}{c}\text { Potassium } \\
\text { feldspar }\end{array}$ & Plagioclase & Quartz & $\begin{array}{c}\text { Mafic } \\
\text { minerals }\end{array}$ \\
\hline 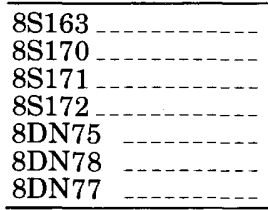 & $\begin{array}{l}27.0 \\
20.2 \\
17.5 \\
19.1 \\
18.1 \\
16.1 \\
17.3\end{array}$ & $\begin{array}{l}38.8 \\
48.9 \\
50.2 \\
47.5 \\
50.0 \\
50.5 \\
51.7\end{array}$ & $\begin{array}{l}23.2 \\
19.4 \\
21.3 \\
23.6 \\
18.1 \\
17.0 \\
16.1 \\
\end{array}$ & $\begin{array}{r}11.0 \\
11.4 \\
10.7 \\
9.8 \\
13.8 \\
16.4 \\
14.9 \\
\end{array}$ \\
\hline
\end{tabular}



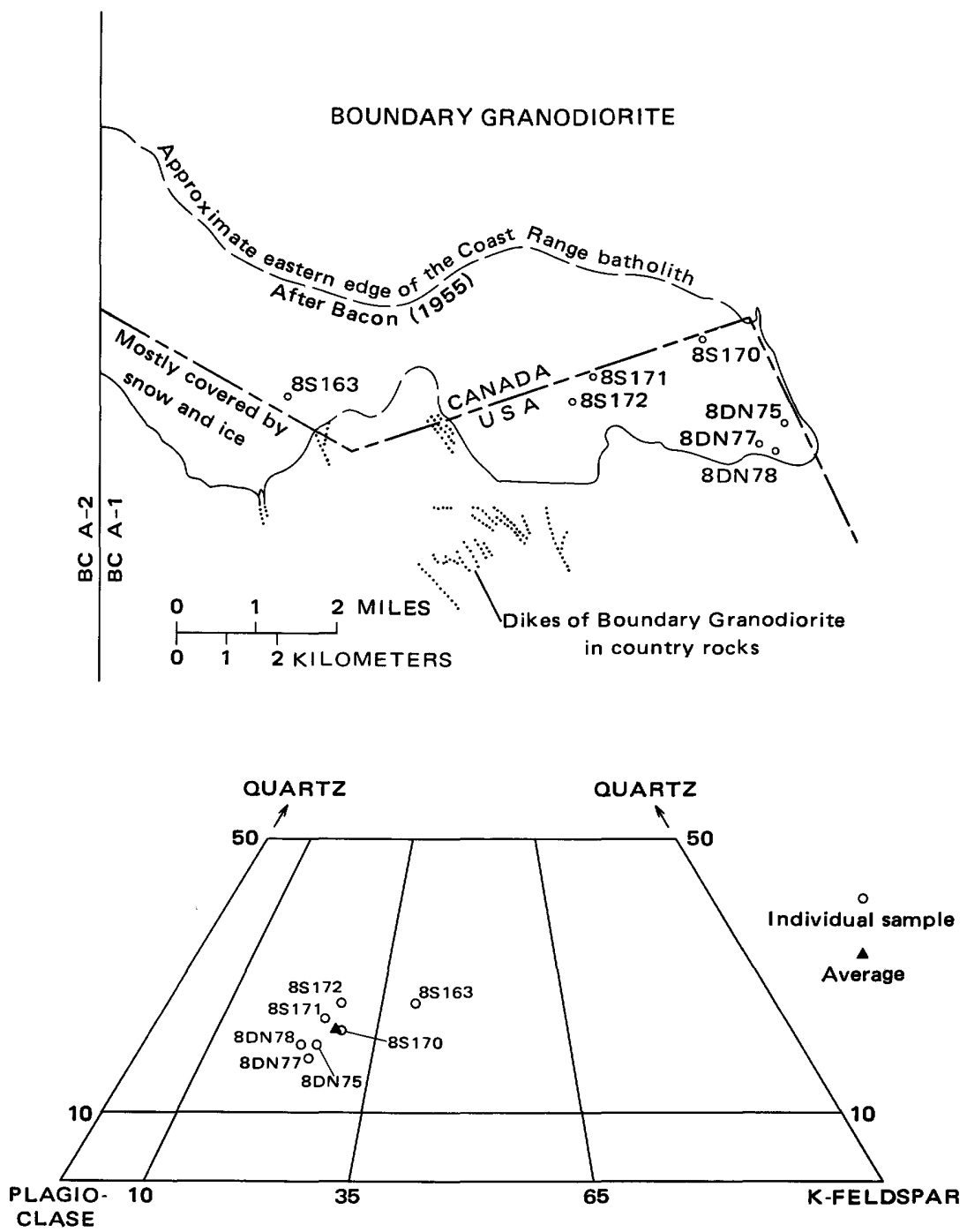

Figure 8.-Location and modal composition of samples from the Boundary Granodiorite. Numbers refer to samples listed in table 6.

Important petrographic features of the Boundary Granodiorite are summarized below.

Lithology. - The pluton is a medium-grained biotite granodiorite. Potassium feldspar. - Both microcline and microcline perthite are present. Grains are anhedral and interstitial. In some samples potassium feldspar has a slight pinkish cast. Subhedral Karlsbad twins are locally present. Grains are $1-5 \mathrm{~mm}$ across. Potassium feldspar ranges 
in abundance from 16.1 to 27.0 percent. Average abundance and standard deviation are $12.6 \pm 2.2$ percent.

Plagioclase.-Plagioclase forms euhedral tablets to subhedral stubby prisms. Most grains touch and even indent one another. Complex twins are common, with thin individual twin lamellae. Grains are strongly zoned with as many as 15-25 oscillatory zones in most grains. $\mathrm{An}_{55}$ (core) to $\mathrm{An}_{15}$ (rim) is the extreme range in zoning, and most crystals are nearly that strongly zoned. Plagioclase ranges in abundance 38.8 to 51.7 percent. Average abundance and standard deviation are $48.2 \pm 4.0$ percent.

Quartz.-Quartz forms generally anhedral strained grains 2-4 mm in size. It ranges in abundance from 16.1 to 23.6 percent. Average abundance and standard deviation are $19.8 \pm 7.5$ percent.

Mafic minerals. - Samples contain more biotite than hornblende. Biotite forms euhedral to subhedral strongly pleochroic grains. $\mathrm{X}=$ straw yellow, $\mathrm{Y}=\mathrm{Z}=$ deep to nearly opaque red brown. Grains are 1-4 $\mathrm{mm}$ across. Apatite inclusions are common. Locally biotite is partly altered to chlorite. Hornblende forms euhedral to subhedral prisms 2-4 mm long which are locally anhedral and "spongy." The pleochroic scheme is $\mathrm{X}=$ medium yellow, $\mathrm{Y}=$ deep brown, $\mathrm{Z}=$ deep green. The mafic minerals range in abundance from 9.8 to 16.4 percent. Average abundance and standard deviation are 12.6 2.2 percent.

Accessory minerals.-Ubiquitous accessory minerals include sphene, opaque minerals, and apatite. Sphene forms euhedral golden-brown crystals $1-2 \mathrm{~mm}$ across. Apatite forms microscopic needles which occur mostly as inclusions in biotite.

Grain size.-Grain size is nearly uniform. Most grains are from 2 to $5 \mathrm{~mm}$.

Texture.-Nearly all samples have a hypidiomorphic slightly inequigranular texture.

Characteristic features.-Characteristic features of the Boundary Granodiorite are (1) mafic minerals generally finer grained than plagioclase, (2) interstitial potassium feldspar, (3) golden yellow sphene grains visible in hand specimen, (4) massive unfoliated texture, and (5) shadowy mafic clots.

\section{DIKES}

Dikes of light-colored porphyritic granodiorite are common north of the West Fork of Texas Creek between Ibex Creek and Chickamin Glacier. A few dikes can be traced into the main body of the Boundary Granodiorite, but most cannot; they have a strong northwest alinement and dip steeply southeast. The dikes associated with the Boundary Granodiorite are nearly identical in mineralogy and texture to dikes associated with the Hyder Quartz Monzonite. 
AGE

The Boundary Granodiorite intrudes the Hazelton(?) Group and the Texas Creek Granodiorite. It is nowhere in contact with the Hyder Quartz Monzonite, so their age relation cannot be determined. Buddington (1929) closely linked the Boundary and Hyder on the basis of composition and age.

An Eocene age of intrusion for the Boundary Granodiorite is indicated by potassium-argon dates on mineral pairs of hornblende and biotite from two fresh samples. One sample was collected in the western part of the pluton, and the other in the eastern. Within the precision of the potassium-argon method, both mineral pairs gave concordant ages of about 50 m.y., about the same as determined for the Hyder Quartz Monzonite.

The ages and data used to obtain them are listed below:

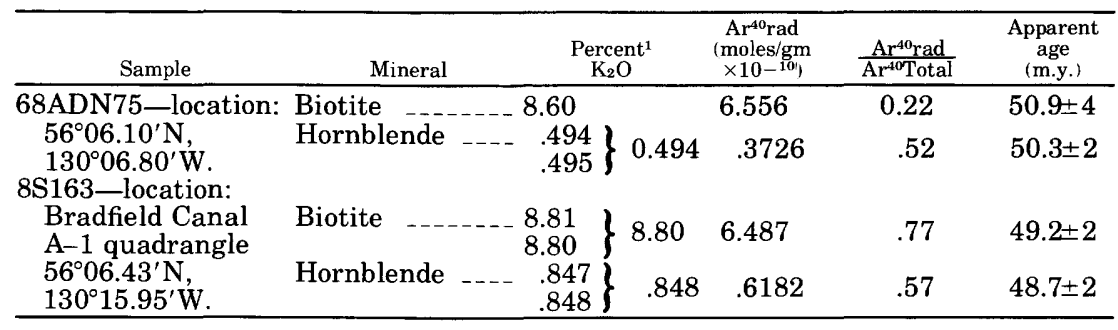

${ }^{1}$ Potassium and argon analyses were done by Lois Schlocker and Jarel von Essen, respectively. Methods and decay constants are the same as those used to calculate the age of the Texas Creek Granodiorite.

\section{CATACLASITE, SCHIST, AND MYLONITE}

A belt of cataclasite, schist, and mylonite about $1.5 \mathrm{~km}$ wide extends from the vicinity of the Mountain View mine northeastward across the Alaska-British Columbia border. It is continuous with an identical belt of cataclastic rocks in Canada mapped by Grove (1971, p. 43-48) and is bounded by younger faults that closely follow Fish and Skookum Creeks. These cataclastic rocks and the associated faults constitute the Fish Creek shear zone.

Most outcrops have a rounded aspect as a result of glaciation. Close examination shows that the surface of many is pitted and jagged owing to spalling and plucking of small rhombs formed by the intersection of numerous subparallel foliations and shear planes. At some localities, collection of hand specimens is difficult, as a hammer blow shatters the rock. Fresh samples are dark shades of green, gray, or black, and less commonly red or purple. Weathering lightens and mutes the colors so that weathered surfaces are shades of tan and buff. The degree of crushing, as well as spacing of individual shears within the belt of cataclastic rocks, is extremely variable. Unsheared lenses exist throughout the belt at all scales. Individual shears, folia- 
tions, and cleavages all strike parallel to the general trend of the belt and dip within a few degrees of vertical.

Most of the cataclastic rocks in this belt were derived from the Hazelton(?) Group; the rest were derived from the Texas Creek Granodiorite. Sufficient relict features are usually visible in hand specimens, particularly on weathered surfaces, to be able to make a reasonable guess at their ancestry, although thin sections are often needed for confirmation. Relict features in cataclasite derived from the Hazelton(?) Group include plagioclase laths, vesicles, individual clast outlines, and vague compositional and size layering. Relict features in rocks derived from the Texas Creek Granodiorite include zoned plagioclase laths, subhedral quartz crystals (absent in the Hazelton(?) Group), and outlines of original euhedral hornblende and biotite grains.

The schist has a strong foliation and abundant minor folds with amplitudes a few centimeters across with steep fold axes. Mineral lineations and quartz rods are well developed. They lie within the foliation and plunge down the dip. Schists are so thoroughly recrystallized that relict features are visible only in thin section.

Mylonite within the belt is similar to cataclasite, except that porphyroclasts are larger, their parentage is more easily recognized, and they have numerous undulatory shear surfaces generally covered with greasy green chlorite. The two rocks grade into one another.

Rocks in this belt have greenschist facies mineral assemblages. Textural and mineralogical reconstitution, however, is far from complete. Plagioclase is present both as euhedral relict phenocryst shapes and as recrystallized xenomorphic grains smaller than $0.05 \mathrm{~mm}$ in the groundmass. All plagioclase is albite. Quartz forms xenomorphic grains smaller than $0.05 \mathrm{~mm}$. It is also present as strained subhedral crystals as large as $3 \mathrm{~mm}$ in rocks derived from the Texas Creek Granodiorite. Green chlorite is present in nearly every sample, although the amount varies. It occurs as vesicle fillings, a pseudomorph after biotite, and as flakes scattered throughout the rock. It is also a ubiquitous constituent of shears and fractures. Calcite is a common constituent and occurs as individual xenomorphic grains and as clumps of a few grains scattered throughout the rock as well as with opaque minerals and chlorite as a replacement product of hornblende. White mica, probably muscovite, occurs as tiny flakes less than 0.02 $\mathrm{mm}$ scattered throughout the rock. Minerals present in minor amounts include sphene, epidote, and opaque minerals.

The cataclasite, schist, and mylonite are younger than both the Texas Creek Granodiorite and the Hazelton(?) Group because the cataclastic rocks formed by crushing and shearing of those two units. The cataclastic rocks are intruded by the unsheared Eocene Hyder 
Quartz Monzonite and mid-Miocene(?) lamprophyre dikes. The age of the cataclastic rocks thus is bracketed somewhere between the Late Triassic or Early Jurassic and Eocene on the basis of evidence available near Hyder.

Grove (1971, p. 85) in describing the adjacent area of British Columbia states "none of the cataclasite zones (sic) mapped was found to extend into Bowser assemblage ${ }^{* * *}$ " His stratigraphic sections also show his Middle and Upper Jurassic Bowser assemblage lying unconformably on cataclastic rocks that are continuous in outcrop with the cataclasite, schist, and mylonite belt that I have mapped. On the basis of evidence available in British Columbia as well as in Alaska, the cataclasite, schist, and mylonite formed in the time interval between the intrusion of the Texas Creek Granodiorite in the Late Triassic or Early Jurassic and deposition of the Bowser assemblage in the Middle and Late Jurassic.

I believe that the cataclasite, schist, and mylonite within the Fish Creek fault zone formed as a result of movement along a regional shear zone and not from the intrusion of the Texas Creek Granodiorite. This long, narrow shear zone separates the Texas Creek Granodiorite and Hazelton(?) Group for less than one-third of its length, including its extension into the adjacent Stewart map area. Near Noname Lake and Silver Creek in British Columbia, nearly a kilometer of unsheared Hazelton(?) Group is sandwiched between the Texas Creek Granodiorite and the cataclastic rocks (Grove, 1971, figs. 3,4 ). The presence of this band of unsheared rocks between the Texas Creek Granodiorite and the Fish Creek fault zone is difficult to explain if the zone formed as a result of intrusion of the Texas Creek Granodiorite. If the cataclasite, schist, and mylonite formed as a result of intrusion of the Texas Creek Granodiorite, cataclastic or protoclastic zones should be present elsewhere along the contacts of the Texas Creek Granodiorite and surrounding country rocks, but there are none.

Another belt of cataclastic rocks, the Bear River cataclasite zone of Grove (1971, p. 85), parallels the cataclastic rock of the Fish Creek fault zone. The Bear River zone is more than $4.5 \mathrm{~km}$ east of the Texas Creek Granodiorite, which makes its formation as a result of the intrusion of the Texas Creek Granodiorite unlikely. The alinement and similarity of these two shear zones suggest that they both had analogous regional structional origin and were not formed by intrusion of the Texas Creek Granodiorite.

\section{LAMPROPHYRE DIKES}

Numerous alined lamprophyre dikes occur throughout the Ketchikan D-1 and Bradfield Canal A-1 quadrangles, but individual dikes 
are too thin to plot on the geologic map. The dikes are part of a Tertiary lamprophyre dike province whose full extent is unknown but which covers more than $15,500 \mathrm{~km}^{2}$ and extends from Portland Canal to the Unuk River (Smith, 1973).

The lamprophyre dikes vary widely in mineralogy, texture, and hand specimen appearance. Fresh dikes are jet black and fine grained. Phenocrysts of euhedral stubby augite, and less commonly plagioclase laths and completely altered olivine grains, constitute less than 5 percent. The groundmass is intergranular or rarely subophitic and is composed of plagioclase, pyroxene, and scarce opaque minerals.

Individual dikes are remarkably uniform over long distances; they rarely bifurcate or change thickness or trend. On steep valley walls dikes only a meter or so thick can be traced as ribbonlike bands from valley floor to ridgetop over vertical distances of hundreds of meters. Individual dikes and dike swarms can be traced on aerial photographs for long distances across the bare glaciated ridges.

Most of the dikes range in thickness from 0.5 to $3 \mathrm{~m}$, although their extreme range is from a few centimeters to more than $15 \mathrm{~m}$. The thinnest dikes may change attitude abruptly and cut across from one joint plane to another for short distances before abruptly terminating or returning to their original direction. Dikes thicker than $0.5 \mathrm{~m}$ rarely change attitude or thickness.

Fewer dikes were seen cutting the Hazelton(?) Group than cutting granitic rocks. Perhaps fewer dikes intruded the metamorphic rocks, but just as likely the dark lamprophyre was more easily overlooked in the similarly colored metavolcanic rocks. Differential erosion strongly emphasized the dikes in areas of granitic rock. Closely spaced longitudinal and cross joints make them more easily eroded, and many dikes are recognized only by deeply incised clefts with parallel walls.

Lamphrophyre intrusion had little effect on the country rock. Contacts are sharp parallel planar surfaces. Apophyses are lacking in all but the thinnest dikes, and baking or chemical alteration of country rock is minor. Most dikes have chilled margins usually narrower than one-tenth the width of the dike.

Many dikes were deuterically altered by fluids remaining in the final stages of crystallization. The deuterically altered dikes are greasy green or gray and have a distinctive texture of interlocking milky plagioclase crystals and shiny black hornblende needles. There are no sharp divisions between fresh and deuterically altered dikes.

The lamprophyre dikes cut the Eocene Hyder Quartz Monzonite and Boundary Granodiorite and are grooved by Pleistocene glaciation. In chemistry and petrography they correlate closely with 
plateau basalts of British Columbia generally regarded as of Miocene age, which may have originally extended much farther west (Souther, 1972). Potassium-argon data on lamprophyre dikes at Anyox and Alice Arm give an age of about 33 m.y. (Oligocene) (E. W. Grove, written commun., 1973). The available data indicate that the lamprophyre dikes were intruded in the 50-m.y. span between the Eocene and the Pleistocene, most likely in the Miocene.

\section{SURFICIAL DEPOSITS}

Surficial deposits are limited mainly to river valleys and their margins and the vicinity of present-day glaciers. Three types of deposits were mapped, largely from aerial photographs.

\section{ALLUVIUM}

Alluvium forms the flat valley floors of most of the larger streams. It consists of poorly consolidated and poorly sorted sand, gravel, and boulders derived, in places, from nearby glacial deposits. Crude bedding is locally present. Most streams are actively depositing large amounts of detritus. In recent years several large floods caused by the sudden outbreak of glacier-dammed Summit Lake have deposited a meter or so of alluvium in the lower valley of the Salmon River and threatened to inundate the town of Hyder (Grove, 1968).

T ALUS

Talus usually occurs as well-defined often coalescing cones along valley walls at the mouths of steep chutes. It also forms a thin veneer on the floor of many bowl-shaped cirques. These deposits are composed of poorly sorted angular and locally derived gravel and boulders. Most talus deposits are unstable and easily triggered into rapid downslope movements of large quantities of debris.

\section{MORAINES}

Moraines resulting from the recent retreat of alpine glaciers are widespread throughout the map area. Locally, small areas of undifferentiated fluvioglacial deposits are included in this unit. The unit is almost entirely confined to valleys where deposits are rapidly reworked by streams. Moraines are composed of very poorly sorted angular to rounded clasts that range in size from fine silt to boulders as large as houses.

\section{STRUCTURE}

The area of this report lies on the east edge of the Coast Range batholithic complex, adjacent to the gently folded sedimentary rocks 
of the Bowser Basin. Rocks in the map area have been subjected to several periods of folding, metamorphism, and granitic intrusion. Consequently the structural history is complex; later events overprint earlier ones.

\section{FOLDS}

The only major fold that could be mapped is the large arch of the Hazelton(?) Group over the Texas Creek Granodiorite. The axis of the arch strikes east-west, roughly parallel to the west fork of Texas Creek and plunges $15^{\circ}-20^{\circ}$ to the west. The arch was formed by doming of the Hazelton(?) Group during the intrusion of the Texas Creek Granodiorite.

Small-scale folds are widespread in the Hazelton(?) Group in the western part of the Bradfield Canal A-1 quadrangle. Most folds are tightly to isoclinally folded on a scale of a few centimeters to tens of centimeters in amplitude. More than one generation may be present at an outcrop. Axial planes dip moderately, often to the north, and axes plunge gently, generally in an east-west direction.

Macroscopic folds were not seen except in a few favorable locations, and the short time available for fieldwork did not permit the detailed observations necessary to relate minor structures to less obvious. major ones. Several folds with wavelengths measured to tens of meters with steeply northward dipping axial planes were seen in the west wall of Chickamin Glacier near the international boundary.

Most folds on all scales seem to predate the intrusion of the Texas Creek Granodiorite. Straight, undeformed dikes that are offshoots of the Texas Creek Granodiorite cut across folds in the Hazelton(?) Group. In general, intrusion rotated axial planes of folds so that they became more nearly parallel to the contact between the Texas Creek Granodiorite and the Hazelton(?) Group and tightened folds, especially those near the contact.

Structures in the Hazelton(?) Group east of the Salmon River are difficult to map because of dense vegetation and absence of distinctive marker horizons. Relations between cleavage, bedding, and sedimentary structures indicate that intense folding has taken place. Bedding, cleavage planes, and axial planes of most mesoscopic folds strike about east-west and dip steeply; many beds are overturned. These details suggest that the beds are tightly to isoclinally folded about nearly east-west axes.

\section{FAULTS}

Faults are not common in the map area. The Hazelton(?) Group is probably cut by small-scale preintrusive faults, but the monotony of the unit makes tracing faults for any distance difficult. The area is cut by a single large fault zone, the Fish Creek fault zone, which 
extends into British Columbia and along which movement has taken place at least twice.

The Fish Creek fault zone trends north-northeast to northeast, ranges in width from a few meters to about $1.5 \mathrm{~km}$, and cuts seven of the units described in this report. The first period of movement took place in the interval between the Late Triassic and Middle Jurassic. The north-northeast-trending belt of cataclasite, schist, and mylonite described (see section "Cataclasite, Schist, and Mylonite") was formed at this time. Minor structures and mineralogy indicate that movement was primarily horizontal and took place at moderate temperatures. Offset of the nearly vertical Texas Creek Granodiorite-Hazelton(?) Group contact suggests right-lateral movement of about $4 \mathrm{~km}$ at this time.

The second period of movement took place in the late Tertiary. Unsheared dikes of Hyder Quartz Monzonite and lamprophyre that intrude the cataclasite, schist, and mylonite along Fish and Skookum Creeks are offset along faults parallel to directions of shearing in the cataclasites. South of Salmon River the fault is marked by a prominent topographic lineament in the Hyder Quartz Monzonite. The fault trace is largely covered by unfaulted alluvium and morainal debris. Locally, offset lamprophyre dikes were seen. Movement was confined to a zone a few tens of meters wide at most. Offset of the vertical Texas Creek-Hyder contact suggests right-lateral movement of about $1 \mathrm{~km}$.

\section{REFERENCES CITED}

Bacon, W. L., 1955, Preliminary map of the Granduc area: British Columbia Dept. Mines, scale about 1 inch to 1 mile, with text.

Bateman, P. C., Clark, L. D., Huber, N. K., Moore, J. G., and Rinehart, C. D., 1963, The Sierra Nevada batholith-a synthesis of recent work across the central part: U.S. Geol. Survey Prof. Paper 414-D, 46 p.

Berg, H. C., Elliott, R. L., Smith, J. G., Pittman, T. L., and Kimball, A. L., 1976, Mineral resources of the Granite Fiords wilderness study area, Alaska: U.S. Geol. Survey Bull. 1403, 143 p.

Bouma, Arnold, and Hollister, C. D., 1973, Deep ocean basin sedimentation, in Turbidites and deep water sedimentation: Soc. Econ. Paleontologists and Mineralogists, Pacific Sec. Pub., Los Angeles, Calif., May 1973, p. 79-118.

Buddington, A. F., 1929, Geology of Hyder and vicinity, southeastern Alaska: U.S. Geol. Survey Bull. 807, 124 p.

Buddington, A. F., and Chapin, Theodore, 1929, Geology and mineral deposits of southeastern Alaska: U.S. Geol. Survey Bull. 800, 398 p.

Byers, F. M., and Sainsbury, C. L., 1957, Tungsten deposits of the Hyder district, Alaska: U.S. Geol. Survey Bull. 1024-F, p. 123-F140.

Carlisle, Donald, 1963, Pillow breccias and their aquagene tuffs, Quadra Island, British Columbia: Jour. Geology, v. 71, p. 48-71.

Evernden, J. F., and Kistler, R. W., 1970, Chronology of emplacement of Mesozoic batholithic complexes in California and western Nevada: U.S. Geol. Survey Prof. Paper 623, $42 \mathrm{p}$. 
Fiske, R. S., Hobson, C. A., and Waters, A. C., 1963, Geology of Mount Rainier National Park, Washington: U.S. Geol. Survey Prof. Paper 444, 93 p.

Forbes, R. B., and Engels, J. C., 1970, $\mathrm{K}^{40 / \mathrm{Ar}^{40}}$ age relations of the Coast Range batholith and related rocks of the Juneau Ice Field area, Alaska: Geol. Soc. America Bull., v. 81, p. 579-584.

Grove, E. W., 1968, Periodic drainage of glacier-dammed Summit Lake: British Columbia Dept. Mines and Petroleum Resources Ann. Rept. 1967, p. 39-40.

1971, Geology and mineral deposits of the Stewart area, northwestern British Columbia: British Columbia Dept. Mines and Petroleum Resources Bull. 58, 219 p.

Hanson, George, 1929, Bear River and Stewart map areas, Cassiar district, B.C.: Canada Geol. Survey Mem. 159, 84 p.

1935, Portland Canal area, British Columbia: Canada Geol. Survey Mem. 175, $179 \mathrm{p}$

Hanson, G. N., and Gast, P. W., 1967, Kinetic studies in contact metamorphic zones: Geochim. et Cosmochim. Acta, v. 31, no. 7, p. 1119-1153.

Hutchison, W. W., 1966, Prince Rupert and Skeena map area, British Columbia: Canada Geol. Survey Paper 66-33, $27 \mathrm{p}$.

1970, Metamorphic framework and plutonic styles in the Prince Rupert region of the Central Coast Mountains, British Columbia: Canadian Jour. Earth Sci., v. 7 , no. 2 , p. $376-405$.

Mehnert, K. R., 1968, Migmatites and the origin of granitic rocks: Amsterdam, Elsevier, 393 p.

Moore, J. G., 1963, Geology of the Mount Pinchot quadrangle, southern Sierra Nevada, California: U.S. Geol. Survey Bull. 1130, 150 p.

Richards, T. A., 1974, Hazelton East-Half, in Report of activities, part A, April to October, 1973: Canada Geol. Survey Paper 74-1, p. 35-37.

Schofield, S. J., and Hanson, George, 1920, Geology and ore deposits of Salmon River district, British Columbia: Canada Geol. Survey Mem. 132, 81 p.

Shapiro, Leonard, and Brannock, W. W., 1962, Rapid analysis of silicate, carbonate, and phosphate rocks: U.S. Geol. Survey Bull. 1144-A, 56 p.

Smith, J. G., 1973, A Tertiary lamprophyre dike province in southeastern Alaska: Canadian Jour. Earth Sci., v. 10, no. 3, p. 408-420.

Smith, J. G., and MacKevett, E. M., The Skolai Group in the McCarthy B-4, C-4, and C-5 quadrangles, Wrangell Mountains, Alaska: U.S. Geol. Survey Bull. 1274-Q, $26 \mathrm{p}$.

Souther, J. G., 1972, Mesozoic and Tertiary volcanism in the Western Canadian Cordillera, in Irving, E., ed., The Ancient oceanic lithosphere: Canada Dept. Energy, Mines and Resources, Earth Physics Br. Pub., v. 42, no. 3, p. 55-58.

U.S. Weather Bureau, 1943, Climatic atlas for Alaska: U.S. Headquarters Army Air Forces, Rept. no. 44, 229 p.

Westgate, L. G., 1922, Ore deposits of the Salmon River district, Portland Canal region: U.S. Geol. Survey Bull. 722, p. 117-140. 
